\title{
Progress of International Hydrogen Production Network for the Thermochemical Cu-Cl Cycle
}

G. F. Naterer ${ }^{1 *}$, S. Suppiah², L. Stolberg ${ }^{3}$, M. Lewis ${ }^{4}$, Z. Wang ${ }^{5}$, I. Dincer ${ }^{6}$, M. A. Rosen ${ }^{7}$, K. Gabriel ${ }^{8}$, E. Secnik ${ }^{9}$, E. B. Easton $^{10}$, I. Pioro ${ }^{11}$, S. Lvov ${ }^{12}$, J. Jiang ${ }^{13}$, J. Mostaghimi ${ }^{14}$, B. M. Ikeda ${ }^{15}$, G. Rizvi ${ }^{16}$, L. Lu ${ }^{17}$, A. Odukoya ${ }^{18}$, P. Spekkens ${ }^{19}$, M. Fowler ${ }^{20}$, J. Avsec ${ }^{21}$

\author{
${ }^{1}$ Memorial University, St. John’s, Newfoundland, Canada \\ 6-13, 16-18 University of Ontario Institute of Technology (UOIT), Oshawa, Ontario, Canada \\ 2, 3 Atomic Energy of Canada Limited (AECL), Chalk River, Ontario, Canada \\ ${ }^{4}$ Argonne National Laboratory, Argonne, Illinois, U.S. \\ 12 Pennsylvania State University, University Park, Pennsylvania, U.S. \\ ${ }^{13}$ University of Western Ontario, London, Ontario, Canada \\ ${ }^{14}$ University of Toronto, Toronto, Ontario, Canada \\ ${ }^{19}$ Ontario Power Generation (OPG), Pickering, Ontario, Canada \\ ${ }^{20}$ University of Waterloo, Waterloo, Ontario, Canada \\ ${ }^{21}$ University of Maribor, Maribor, Slovenia
}

1* Corresponding Author: Professor and Dean, Faculty of Engineering and Applied Science, Memorial University of Newfoundland, St. John’s, Newfoundland, A1B 3X5, Email: gnaterer@mun.ca; Phone: (709) 864-8864, Fax: (709) 864-8975

${ }^{2}$ Manager, Hydrogen Isotopes Technology Branch, AECL, Chalk River, Ontario, Canada, K0J 1J0

${ }^{3}$ Scientist, Hydrogen Isotopes Technology Branch, AECL, Chalk River, Ontario, Canada, K0J 1J0

${ }^{4}$ Chemist, Chemical Engineering Division, Argonne National Laboratory, 9700 S. Cass Avenue, Argonne, Illinois, USA, 60439

${ }^{5}$ Hydrogen Program Director, UOIT, 2000 Simcoe Street North, Oshawa, Ontario, Canada, L1H 7K4

${ }^{6}$ Professor of Mechanical Engineering, UOIT, 2000 Simcoe Street North, Oshawa, Ontario, Canada, L1H 7K4

${ }^{7}$ Professor of Mechanical Engineering, UOIT, 2000 Simcoe Street North, Oshawa, Ontario, Canada, L1H 7K4

${ }^{8}$ Professor of Mechanical Engineering, UOIT, 2000 Simcoe Street North, Oshawa, Ontario, Canada, L1H 7K4

${ }^{9}$ Research Laboratory Manager, Faculty of Engineering and Applied Science, UOIT, 2000 Simcoe Street North, Oshawa, Ontario, Canada, L1H 7K

${ }^{10}$ Assistant Professor of Chemistry, UOIT, 2000 Simcoe Street North, Oshawa, Ontario, Canada, L1H 7K42

${ }^{11}$ Associate Professor, Faculty of Energy Systems and Nuclear Science, UOIT, 2000 Simcoe Street, Oshawa, Ontario, Canada

${ }^{12}$ Professor of Energy and Mineral Engineering, Department of Materials Science and Engineering, Pennsylvania State University, 207 Hosler Building, University Park, PA 16802

${ }^{13}$ Professor and NSERC/UNENE Senior Industrial Research Chair, Electrical and Computer Engineering, University of Western Ontario, London, Ontario, Canada, N6A 5B9

${ }^{14}$ Distinguished Professor in Plasma Engineering, Department of Mechanical and Industrial Engineering, University of Toronto, Toronto, Ontario, Canada, M5S 3E5

${ }^{15}$ Associate Professor, Faculty of Energy Systems \& Nuclear Science, 2000 Simcoe Street North, Oshawa, Ontario, Canada, L1H $7 \mathrm{~K} 4$

${ }^{16}$ Associate Professor of Mechanical Engineering, UOIT, 2000 Simcoe St., Oshawa, ON, Canada, L1H 7K4

${ }^{17}$ Assistant Professor, Faculty of Energy Systems and Nuclear Science, UOIT, 2000 Simcoe Street, Oshawa, Ontario, Canada, L1H 7K4

${ }^{18}$ Research Associate, Faculty of Science, UOIT, 2000 Simcoe Street, Oshawa, Ontario, Canada, L1H 7K4

${ }^{19}$ Vice President of Science and Technology Development, OPG, 889 Brock Road, Pickering, Ontario, Canada

${ }^{20}$ Assistant Professor of Chemical Engineering, University of Waterloo, 200 University Ave., Waterloo, ON, Canada, N2L 3G1

${ }^{21}$ Associate Professor, Faculty of Energy Technology, University of Maribor, Hocevarjev trg 1, 8270 Krsko, Slovenia 


\begin{abstract}
This paper presents recent advances by an international team which is developing the thermochemical copperchlorine $(\mathrm{Cu}-\mathrm{Cl})$ cycle for hydrogen production. Development of the $\mathrm{Cu}-\mathrm{Cl}$ cycle has been pursued by several countries within the framework of the Generation IV International Forum (GIF) for hydrogen production with the next generation of nuclear reactors. Due to its lower temperature requirements in comparison with other thermochemical cycles, the $\mathrm{Cu}-\mathrm{Cl}$ cycle is particularly well matched with Canada's Generation IV reactor, SCWR (Super-Critical Water Reactor), as well as other heat sources such as solar energy or industrial waste heat. In this paper, recent developments of the $\mathrm{Cu}-\mathrm{Cl}$ cycle are presented, specifically involving unit operation experiments, corrosion resistant materials and system integration.
\end{abstract}

\title{
1. Introduction
}

It has become increasingly urgent for countries to reduce greenhouse gas (GHG) emissions amidst growing worldwide needs for a sustainable energy supply. The installed capacity of renewable forms of energy such as solar and wind energy has grown rapidly. However, these are intermittent, unstable and yield varying power output. Sunlight is unavailable at night and the magnitude of incoming solar radiation varies monthly and seasonally. The power demand on the electricity grid varies hourly. As a result, a suitable medium is needed to store and later distribute this intermittent and off-peak energy, in order to reduce "peaks and valleys" in the load profile. Hydrogen is a promising clean energy carrier which can serve this role as an effective medium for large-scale and long-term storage of solar and wind energy.

Numerous technologies have been developed for sustainable production of hydrogen. Due to energy losses with electrolysis associated with the intermediate conversion of thermal energy to electricity, thermochemical cycles have a promising advantage of potentially higher efficiency than electrolysis. This paper presents an overview of the latest advances in the copper-chlorine $(\mathrm{Cu}-\mathrm{Cl})$ cycle of thermochemical hydrogen production. It specifically examines and presents recent advances by an international team since the time of an earlier review paper by Naterer et al. [1] involving nuclear hydrogen production. Syed et al. [2] reported that hydrogen can be effectively used in integrated energy systems that use both nuclear and renewable energy for base load and mobility applications.

Thermochemical cycles use two or more intermediate compounds in a sequence of chemical and physical processes that split water into hydrogen and oxygen. The intermediate compounds are recycled internally within a closed loop. Although over 200 possible thermochemical cycles have been proposed in the past [3, 4], very few have progressed beyond concepts and theories to working demonstrations that show practical feasibility of the processes. Three of the prominent cycles are the sulfur-iodine (S-I), hybrid sulfur and copper-chlorine (Cu-Cl) cycles, under 
development worldwide by the USA (General Atomics, Savannah River National Laboratory, among others), Japan (Japan Atomic Energy Agency, JAEA), France (Commissariat à l'Energie Atomique, CEA), Korea (Atomic Energy Research Institute; KAERI)), South Africa (Electric Supply Commission; Eskom), China (Tsinghua University), and others [5, 6]. A Canadian-led network consisting of the University of Ontario Institute of Technology (UOIT), Atomic Energy of Canada Limited (AECL), Argonne National Laboratory (ANL), UNENE (University Network of Excellence in Nuclear Engineering; Canada), among others, is developing an integrated large lab-scale demonstration of the CuCl cycle, through the Generation IV International Forum (GIF; [7]). Other cycles under development around the world include the iron-chlorine (Fe-Cl) [8], copper-sulfate $\left(\mathrm{Cu}-\mathrm{SO}_{4}\right)$ [8] cerium-chlorine $(\mathrm{Ce}-\mathrm{Cl})$ [8], vanadium-chlorine $(\mathrm{V}$ Cl) [8], and the hybrid chlorine cycle [8].

A number of significant advantages exist for the $\mathrm{Cu}-\mathrm{Cl}$ cycle over other thermochemical cycles, such as much lower operating temperatures (maximum $530{ }^{\circ} \mathrm{C}$ ), lower demands on materials of construction, common chemical agents, reactions going to full completion, and a relatively low electrochemical cell voltage. Approximately 43\% net efficiency is envisioned with the $\mathrm{Cu}-\mathrm{Cl}$ cycle, which is a significant margin of improvement of more than one-third over electrolysis [9]. The unit operations of a large lab-scale $\mathrm{Cu}-\mathrm{Cl}$ cycle have been successfully demonstrated by the UOIT-led team. The efforts are envisioned to eventually scale up the cycle to a pilot plant and ultimately a commercial plant which can be linked with nuclear, solar or other heat sources (such as industrial waste heat from steel recycling or cement plants). The $\mathrm{Cu}-\mathrm{Cl}$ cycle promises to achieve higher efficiencies, lower environmental impact and lower costs of hydrogen production than other existing technologies. Although there are major advantages with the $\mathrm{Cu}-\mathrm{Cl}$ cycle for hydrogen production, there are also significant challenges, including the corrosive working fluids and handling and transport of solid materials between unit operations.

The Cu-Cl cycle consists of three chemical reaction steps (electrolysis, hydrolysis and thermolysis) as well as further auxiliary physical processes (water removal by drying / crystallization, species separation and heat exchangers). Electrolysis of cuprous chloride in hydrochloric acid to cupric chloride and hydrogen has been successfully demonstrated by AECL [10,11] and Balashov et al. [12]. Daggupati and co-workers [13, 14] presented a number of studies on drying of aqueous cupric chloride after it exits the electrolyzer and prior to entering the hydrolysis reactor. The cupric chloride is then converted to solid copper oxychloride in a spray reactor [15] or fluidized bed [16 - 19], through an endothermic non-catalytic gas-liquid hydrolysis reaction that operates between 350 and $400{ }^{\circ} \mathrm{C}$. Copper oxychloride then decomposes to release oxygen gas [20] and molten $\mathrm{CuCl}$, from which heat is recovered and recycled internally [21, 22].

Aspen Plus simulations of these processes [23, 24] have identified cycle modifications to reduce the steam input requirements [25] and identify optimal system parameters and operating conditions [26]. Orhan et al. [27 - 32] 
and Ozbilen et al. [33] conducted simulations with EXCEM (exergy-cost-energy-mass method) to improve the economic viability of the cycle, by relating capital costs with thermodynamic losses in the system. Further simulations analyzed the environmental emissions, impacts and comparisons against other methods of hydrogen production such as electrolysis [34 - 37].

An intermediate heat exchanger provides the necessary transfer of thermal energy from a nuclear plant to endothermic processes in a thermochemical hydrogen plant. Also, it is needed to ensure no tritium transport from the heavy to light water side and then the hydrogen plant [38]. Zamfirescu et al. [39 - 43] examined chemical heat pumps to upgrade waste heat from nuclear plants at successively higher temperatures in exothermic reactors, i.e., salt/ammonia or MgO/vapor chemical heat pumps. Ghandehariun et al. [44] performed a pinch analysis to establish the most effective methods of heat upgrading within the $\mathrm{Cu}-\mathrm{Cl}$ cycle. Lukomoski et al. [44 - 48] and Naidin et al. [49] presented various nuclear plant configurations for co-generation of electricity and hydrogen, including thermodynamic and heat transfer studies of direct, indirect, no-reheat, and single reheat cycles linked with the $\mathrm{Cu}-\mathrm{Cl}$ cycle. Safety aspects of nuclear hydrogen plants have been reported by Sun and co-workers [50 - 52], as well as Al-Dabbagh et al. [53 - 55], based on a Dynamic Flowgraph Methodology (DFM) that analyzes the behavior of control systems in the $\mathrm{Cu}-\mathrm{Cl}$ cycle.

Access to reliable thermophysical data for high temperature $\mathrm{Cu}-\mathrm{Cl}$ compounds has major importance for development of the engineering systems in the $\mathrm{Cu}-\mathrm{Cl}$ cycle. Molecular simulations of aqueous solution solubility have been reported for various working fluids in the $\mathrm{Cu}-\mathrm{Cl}$ cycle [56, 57]. Trevani et al. [58] identified thermophysical properties of copper complex species in $\mathrm{HCl}$ solutions that are responsible for copper crossover in the electrolysis cell. Thermochemical properties of copper oxychloride have been examined by Ikeda and Kaye [59], as well as Trevani et al. [60]. The method adopted by Ikeda and Kaye [59] involved the use of stoichiometric amounts of $\mathrm{CuO}$ and $\mathrm{CuCl}_{2}$. Theoretical models of various copper / chlorine compound properties have also been developed based on nonequilibrium statistical thermodynamics [61, 62]. Ferrandon et al. [63] examined the reactant properties related to the kinetics of the hydrolysis, thermolysis, and oxidation reactions. Material properties of the anode of the $\mathrm{CuCl} / \mathrm{HCl}$ electrolysis cell were reported by Ranganathan, Easont and co-workers [64 - 67].

Past studies have examined hydrogen applications and case studies involving the transportation sector [68 70], upgrading of bitumen in Alberta's oil sands [71], as well as hydrogen vehicles and trains in Ontario, Canada [72 - 77]. This paper focuses on hydrogen production, specifically the latest developments in the Cu-Cl cycle involving unit scale operations, materials corrosion and systems integration. It describes recent progress of a Canadian-led international team towards industrialization of the $\mathrm{Cu}-\mathrm{Cl}$ cycle, including a number of institutions from Canada (UOIT, Memorial University of Newfoundland, University of Toronto, University of Guelph, University of Western Ontario, 
University of Waterloo, McMaster University), U.S. (ANL; Argonne National Laboratory, PSU; Pennsylvania State University), Slovenia (University of Maribor), Romania (National Hydrogen and Fuel Cell Centre), and Argentina (Atomic Energy National Commission).

\section{Thermochemical Copper-Chlorine (Cu-Cl) Cycle}

The $\mathrm{Cu}-\mathrm{Cl}$ cycle consists of a sequence of physical and chemical processes that decompose water into hydrogen and oxygen, using intermediate copper and chloride compounds, in a closed internal loop that recycles all chemicals on a continuous basis. Table 1 and Figure 1 depict the four main process steps in the $\mathrm{Cu}-\mathrm{Cl}$ cycle and a schematic realization of the cycle, respectively. Although several variations of the $\mathrm{Cu}-\mathrm{Cl}$ cycle have been reported in past literature (5-step, 4-step and 3-step cycles), this paper will focus on the 4-step cycle (Table 1), due to its anticipated advantages over other variations in terms of better thermal efficiency and practical viability. In the 4-step cycle, the water splitting process begins in the hydrolysis reactor where steam reacts with cupric chloride (solid) to form copper oxychloride (solid) and hydrochloric gas. The exiting copper oxychloride later decomposes in the next process (thermolysis) to release oxygen. Also, solidified $\mathrm{CuCl}$ product from the thermolysis reactor is dissolved in the condensed hydrochloric gas from the hydrolysis reactor to release hydrogen gas in the $\mathrm{CuCl} / \mathrm{HCl}$ electrolyzer.

\section{CuCl / HCl Electrolysis (Step 1)}

\subsection{Process Description}

Hydrogen is produced from the electrochemical reaction of $\mathrm{CuCl}$ and $\mathrm{HCl}$ in an electrolytic cell. At the anode, the $\mathrm{Cu}(\mathrm{I})$ ion is oxidized to $\mathrm{Cu}(\mathrm{II})$ and the hydrogen ion is reduced at the cathode (see Fig. 2). Anionic $\mathrm{Cu}(\mathrm{I})$ species are formed in solution when $\mathrm{CuCl}$ is dissolved in an $\mathrm{HCl}$ electrolyte. Anionic $\mathrm{Cu}(\mathrm{I})$ species will diffuse through the membrane in the absence of an electric field. The effect of an electric field on the diffusion of anionic $\mathrm{Cu}(\mathrm{I})$ species is currently being investigated. Cationic $\left(\mathrm{CuCl}^{+}\right)$or neutral $\left(\mathrm{CuCl}_{2}\right) \mathrm{Cu}$ species produced at the anode can permeate through the membrane. Once in the catholyte, copper deposition can take place at the cathode. The overall cell reaction can be expressed as

$$
2 \mathrm{CuCl}+2 \mathrm{HCl} \rightarrow 2 \mathrm{CuCl}_{2}+\mathrm{H}_{2}
$$

At the anode, several complex forms of $\mathrm{Cu}(\mathrm{I})$ and $\mathrm{Cu}(\mathrm{II})$ chloride can be produced during the following reactions:

$$
\begin{aligned}
& \mathrm{Cu}^{+}(\mathrm{aq})+\mathrm{n} \mathrm{Cl}^{-}(\mathrm{aq}) \leftrightarrow \mathrm{CuCl}_{\mathrm{n}}{ }^{1-\mathrm{n}} \\
& \mathrm{Cu}^{2+}(\mathrm{aq})+\mathrm{n} \mathrm{Cl}^{-}(\mathrm{aq}) \leftrightarrow \mathrm{CuCl}_{\mathrm{n}}{ }^{2-\mathrm{n}}
\end{aligned}
$$


$\mathrm{Cu}(\mathrm{I})$ can exist as several altered anionic species (e.g. $\mathrm{CuCl}_{2}{ }^{-}, \mathrm{CuCl}_{3}{ }^{2-}$ ) in a chloride aqueous solution. The relative proportions of each species are dependent on the concentration of chloride ions in the electrolyte. The anodic reaction proceeds by the electro-oxidation of $\mathrm{Cu}(\mathrm{I})$ species to $\mathrm{Cu}(\mathrm{II})$ species.

Since the crossover of copper species from the anolyte into the catholyte, which is typically an $\mathrm{HCl}$ solution, can adversely affect the performance of the electrolyzer in terms of cell voltage, several team members (AECL, ANL, PSU) are actively involved in the development of alternative membranes for the electrolyzer which are capable of stopping copper species crossover. The cell voltage needs to be as low as possible to reduce energy usage and the current density should be as high as possible to minimize capital costs and maximize hydrogen production efficiency. Research efforts at AECL, ANL and PSU have focused on three main areas: (1) improve membrane properties to reduce and/or eliminate copper species crossover; (2) modify the electrolyzer's hardware and operating parameters to increase current density for a given cell voltage; and (3) develop a methodology to achieve long-term durability of the electrolyzer and determine degradation mechanisms.

\subsection{Electrolyzer Performance (AECL)}

AECL has successfully demonstrated the production of hydrogen over a period of 341 hours with a $\mathrm{CuCl} /$ $\mathrm{HCl}$ electrolyser. The results from the long term test are reported in Fig. 3a. According to this figure, the cell voltage between $23 \mathrm{~h}$ and $341 \mathrm{~h}$ varied from $0.685 \mathrm{~V}$ to $0.714 \mathrm{~V}$, respectively. Between $23 \mathrm{~h}$ and $238 \mathrm{~h}$, the cell voltage was at or below $0.705 \mathrm{~V}$, and between $74 \mathrm{~h}$ and $238 \mathrm{~h}$ the cell voltage can be described as steady-state. Overall, the performance of the cell in terms of cell voltage was very good during this long term test.

The experimental catholyte copper species concentration data obtained in-situ during the test is also plotted on Fig 3a. The dashed line on this figure drawn at a copper species concentration of 1 ppm represents the detection limit of the uv-visible spectrophotometric technique that was used for the analysis of copper (I) and copper (II) species concentrations. As this figure shows, the catholyte copper species concentration was below the detection limit of the analytical technique for the first $174 \mathrm{~h}$ of the experiment. Between $174 \mathrm{~h}$ and $341 \mathrm{~h}$, the catholyte copper species concentration slowly increased to $2.7 \mathrm{ppm}$.

The cell voltage, $\mathrm{V}_{\text {cell }}$, can be estimated from the following expression:

$\mathrm{V}_{\text {cell }}=\mathrm{E}+\eta_{\mathrm{a}}+\eta_{\mathrm{c}}+\eta_{\text {conc }}+\mathrm{IR}_{\mathrm{a}}+\mathrm{IR}_{\mathrm{c}}+\mathrm{IR}_{\mathrm{m}}+\mathrm{IR}_{\mathrm{h}}+\mathrm{IR}_{\text {cont }}=\mathrm{E}+\eta_{\mathrm{a}}+\eta_{\mathrm{c}}+\eta_{\text {conc }}+\mathrm{IR}_{\Omega}$

where $E$ is the equilibrium potential, $\eta_{a}$ is the activation overpotential for the $\mathrm{Cu}(\mathrm{I})$ oxidation reaction, $\eta_{c}$ is the activation overpotential for the hydrogen production reaction, $\eta_{\text {conc }}$ is the concentration overpotential, and $I_{a}, I_{c}$, $\mathrm{IR}_{\mathrm{m}}, \mathrm{IR}_{\mathrm{h}}, \mathrm{IR}_{\mathrm{cont}}$ and $\mathrm{IR}_{\Omega}$ are the ohmic voltage drops of the anolyte, catholyte, membrane, external hardware, contact resistance and total ohmic resistance. $\mathrm{R}_{\Omega}$ is measured in-situ by electrochemical impedance spectroscopy. 
The cell voltage and cell resistance decrease with increasing temperature at constant current density as Fig. 3b shows. The data presented here correspond to an $\mathrm{HCl}$ concentration of $12 \mathrm{M}$. The main contribution to the total cell resistance is ohmic losses within the cell, which decrease with increasing temperature and decreasing $\mathrm{HCl}$ concentration. The ohmic resistance decreases by about $40 \%$ when the molar concentration is reduced from $12 \mathrm{M} \mathrm{HCl}$ to $6 \mathrm{M} \mathrm{HCl}$ at $45^{\circ} \mathrm{C}$. When the solution temperature is increased to $65^{\circ} \mathrm{C}$, the ohmic resistance only drops by about $30 \%$ over a similar concentration range. The change in temperature leads to thermodynamic irreversiblities which reduce the open circuit voltage. Similarly, concentration gradients also yield irreversibilities within the cell. The activation losses are relatively small and show a weak dependence on temperature. When the temperature of the solution increases from $45^{\circ} \mathrm{C}$ to $65^{\circ} \mathrm{C}$, the results indicate that the activation losses decrease by less than $5 \%$. The small activation losses indicate that the electrochemical half reactions are very facile. Measurements indicated that the process temperature can be reduced if the ohmic losses are reduced. Over the current density range 0.1 to $0.5 \mathrm{~A} \bullet \mathrm{cm}^{-2}$, the cell voltage was found to linearly decrease with increasing temperature. Extrapolated experimental data showed that the temperature required to produce hydrogen at a current density of $0.5 \mathrm{~A} \cdot \mathrm{cm}^{-2}$ and cell voltage of $0.7 \mathrm{~V}$ decreases with increasing $\mathrm{HCl}$ concentration. Under process conditions where the $\mathrm{Cu}^{2+} / \mathrm{Cu}^{+}$concentration ratio is high, the temperature required to produce $\mathrm{H}_{2}$ at a current density of $0.5 \mathrm{~A} \cdot \mathrm{cm}^{-2}(0.7 \mathrm{~V})$ will exceed $100^{\circ} \mathrm{C}$.

\subsection{Membrane Performance (Pennsylvania State University and Argonne National Laboratory)}

To improve the very thin (1mm thick) porous polyethylene membrane’s mechanical stability, various coatings were applied and tested. Various pressing procedures for the Nafion ${ }^{\circledR}$-based membrane were investigated. Different procedures and configurations were examined for fabricating the membrane electrode assemblies (MEAs). Also, different hardware and operating parameters, such as flow rates, catalysts and catalyst loadings, as well as anolyte and catholyte compositions, were studied to determine their effect on cell performance and potential to reduce costs and/or increase efficiency. For example, changes in flow field designs were found to affect performance with the porous polyethylene membrane. Electrochemical impedance spectroscopy was used to determine degradation mechanisms with the goal of improving lifetime performance. A $6.45 \mathrm{~cm}^{2}$ single cell was used. In addition, a full size, $300 \mathrm{~cm}^{2}$ active area, single cell was fabricated.

Potential membrane materials were screened using the permeability of dissolved Cu(II) species and conductivity at $25{ }^{\circ} \mathrm{C}$. Table 2 shows a comparison of these properties, selectivity values (defined as the ratio of conductivity to permeability, or the ratio of hydrogen transport to copper transport), as well as current costs for Nafion ${ }^{\circledR}$ 117, Nafion ${ }^{\circledR}$-based and porous polyethylene. Cost was a factor in the evaluation of the various membranes. The cost 
of the porous polyethylene is about 55 times less than Nafion ${ }^{\circledR} 117$, while the cost for the Nafion ${ }^{\circledR}$-based membranes is higher than Nafion ${ }^{\circledR} 117$ because of additional processing. While the porous polyethylene is least expensive, it may require a coating for additional mechanical stability and the cost is unknown.

Electrolyzer performance with Nafion ${ }^{\circledR}$-based membranes was examined at PSU. Teflon or PFA components replaced all metallic components. Teflon diaphragm pumps replaced peristaltic pumps. The HCl concentration in the anolyte and catholyte was reduced from $11 \mathrm{M}$ to $6-7 \mathrm{M}$. The $\mathrm{CuCl}$ concentration was $2 \mathrm{M}$. Additional heating tapes, insulation and oil baths for bringing the recycled solutions to test temperature were incorporated into the design. Hydrogen production was measured by weighing the water displaced by the exit gas after drying and $\mathrm{HCl}$ removal.

Figure 4a shows a polarization curve using the Nafion ${ }^{\circledR}$-based membrane for two flow rates after a 24 hr test. The test was performed at $80 \mathrm{C}$, atmospheric pressure, and $0.8 \mathrm{mg} / \mathrm{cm}^{2} \mathrm{Pt}$ loading on the Nafion ${ }^{\circledR}$-based membrane. The flow field was serpentine. At the target voltage of $0.7 \mathrm{~V}$, the measured current densities were 0.46 and $0.51 \mathrm{~A} / \mathrm{cm}^{2}$ for flow rates of 59 and $130 \mathrm{~mL} / \mathrm{min}$, respectively. These values exceed the 2012 milestone value and approach the 2015 target. Figure 4b shows a hydrogen production efficiency of 95-100\% for the 24 hour period. Experimental values were within a few percent of values predicted by Faraday's Law. This indicates there were no parasitic losses due to reduction of copper ions. No copper deposits were observed on any of the components of the cell after the tests. A subsequent test was run for 36 hrs with the same results. However, one test showed a decreasing current density with time. The explanation for degradation of performance is not understood at this time.

Tests were also conducted at $0.7 \mathrm{~V}$ with a porous polyethylene membrane in a small electrolyzer, with an active area of $6.45 \mathrm{~cm}^{2}$, at $80{ }^{\circ} \mathrm{C}$, deionized water as the catholyte and $2 \mathrm{~mol} \mathrm{CuCl}$ in $10 \mathrm{~mol} / \mathrm{L} \mathrm{HCl}$ as the anolyte. The serpentine flow field had a slightly lower current density $\left(0.12 \mathrm{~A} / \mathrm{cm}^{2}\right)$ than the carbon felt design $\left(0.16 \mathrm{~A} / \mathrm{cm}^{2}\right)$ when the Pt loading was $0.5 \mathrm{mg} / \mathrm{cm}^{2}$ on both the anode and cathode. The type of coating on the membrane had a significant effect. For the same Pt loading on the carbon felt cathode ( $0.5 \mathrm{mg} / \mathrm{cm}^{2}$ but none on anode), the current density was $0.3 \mathrm{~A} / \mathrm{cm}^{2}$ when the porous polyethylene membrane was coated with a ceramic and $0.19 \mathrm{~A} / \mathrm{cm}^{2}$ when coated with Nafion ${ }^{\circledR}$. When the porous polyethylene was coated with Nafion ${ }^{\circledR}$ and the Pt loading was decreased from 2.0 to $0.5 \mathrm{mg} / \mathrm{cm}^{2}$, the current density was only marginally impacted as it decreased from 0.19 to $0.18 \mathrm{~A} / \mathrm{cm}^{2}$. Results suggested that a carbon felt flow field, a ceramic coating on the porous polyethylene, and $0.5 \mathrm{mg} \mathrm{Pt} / \mathrm{cm}^{2}$ are preferred to a serpentine flow field and no coating or a Nafion ${ }^{\circledR}$ coating on the porous polyethylene membrane.

\section{Water Removal from Aqueous Cu (II) Chloride (Step 2)}




\subsection{Spray Drying Experiments (UOIT)}

The drying process of aqueous copper (I) chloride can be expressed as: $2 \mathrm{CuCl}_{2}$ (aq) $\rightarrow 2 \mathrm{CuCl}_{2}$ (s). The water removed is supplied to the hydrolysis reactor to produce copper oxychloride $\left(\mathrm{Cu}_{2} \mathrm{OCl}_{2}\right)$ and $\mathrm{HCl}$ gas. The solid $\mathrm{CuCl}_{2}$ particles are supplied to the hydrolysis reaction as a product of the spray drying process. Spray drying of $\mathrm{CuCl}_{2}$ is accomplished by the atomization of the solution into microscopic particles. This is an energy intensive process, but can be achieved at relatively low temperatures. The energy consumed in the hydrolysis process is dependent on the concentration of $\mathrm{CuCl}_{2}$. For example, the slurry form of $\mathrm{CuCl}_{2}$ requires about five times the heat required by an aqueous solution.

The stages of drying and particle formation are illustrated in Fig. 5. The initial liquid jet leaving the spray drying nozzle is normally at ambient conditions. Upon initial droplet breakup, the jet is heated to saturation conditions. As the temperature of the liquid increases and droplets are formed, the droplet becomes saturated with solute, at the first stage of drying (Fig. 5). Once saturation conditions exist, crystal nucleation starts and a crust is formed at the outer surface of the droplet. Due to capillary action, the surface of the droplet remains wet at this stage. Depending on the heat absorbed by the droplet compared to the water to be evaporated, the droplet may form a crust all around or only at the side of the droplet. Shear forces on the outside of the droplet will move nucleation points to one side of the droplet as the internal fluid transport occurs due to surface shear stresses. As more solution migrates to the surface of the particle, a smooth surface is formed. This surface may fill in any pores found on the surface. As drying continues, the second stage of drying begins as the surface of the particle becomes dry and the wet core shrinks within the particle. Evaporation occurs within the droplet through mass transfer of moisture within the crust. Mechanisms of moisture movement during the non-saturated surface drying period may cause particles to inflate, distort or shrink. Some may form an internal or external skin, the particles may crack, case harden, or fracture completely into dust. After the crust is formed, if the porosity is too low to allow vapour to escape, moisture will escape from the centre of the crust through a blowhole (see measured formations in Fig. 6). Blowholes are evidence of internal water evaporation and a shrinking drying core.

At UOIT, a Yamato D-41 spray dryer was used for the spray drying experiments to produce solid Cu (II) chloride particles from an aqueous $\mathrm{CuCl}_{2}$ solution. A schematic of the experimental apparatus is shown in Fig. 7. The final product characteristics (powder bulk density, particle size and distribution, moisture content, particle morphology, surface structure, particle flowability) were controlled by adjusting the process parameters (atomization liquid flow rate, atomization pressure, drying air inlet temperature, nozzle diameter and solid concentration in the liquid) during spray drying. In the spray drying experiments, a liquid solution was pumped with a peristaltic pump to the pneumatic atomization nozzle. Dry compressed air was mixed with the liquid solution in a two fluid nozzle. Drying 
air was drawn from the atmosphere by a filter compressor through a control valve to the electric heater. The dried powder product was separated from the air using a cyclone separator. Before releasing the air, a venture scrubber was used to clean the air free of any suspended particulate. Sample drying results of the measured moisture content of dried particles over time, as well as corresponding empirical correlations, are shown in Fig. 8.

\subsection{Crystallization (UOIT)}

An alternative process under investigation for water separation is crystallization. This is a process of formation of solid crystals precipitating from the aqueous solution. It is a chemical solid-liquid separation technique, whereby mass transfer of a solute occurs from the liquid to solid crystalline phase. The crystallization occurs by precipitation, through a variation of the solubility conditions of the solute in the solvent, rather than precipitation due to chemical reaction. The solubility experimental apparatus and crystallization bath at UOIT are shown in Fig. 9. The objectives were to demonstrate the most economical removal of water from aqueous $\mathrm{CuCl}_{2}$. Images of sequential stages of the crystallization process are illustrated in Fig. 10. Figures 10a-e show the crystal appearance before the end state, just reaching the end state, after a clear solution was filtered away, after it is squeezed with filter paper, and after removal of hydrated water.

Characteristics of heat recovery through the crystallization process are shown in Table 3. The measured and theoretical quantities of anhydrous $\mathrm{CuCl}_{2}$ after crystallization are listed. Experimental measurements with forced and natural convection are about 36\% higher than the predicted results, possibly due to heat losses to the environment. The crystallization experiments yielded empirical correlations based on the dissolution enthalpy to establish the solubility at different temperatures. The precipitated quantity of cupric chloride is more than $40 \%$ larger than the equilibrium solubility, due to a temporary non-equilibrium stable state of crystallization. Heat transfer has a more significant influence than mass diffusion in the crystallization process. It was concluded that crystallization is a promising method for concentrating the $\mathrm{CuCl}_{2}$ solution in a reasonable time and large scale.

\section{Hydrolysis Reaction (Step 3)}

\subsection{Process Description}

The hydrolysis reaction is an endothermic non-catalytic gas-solid reaction that operates in a fluidized bed between 350 and $400^{\circ} \mathrm{C}$, as follows:

$$
\mathrm{H}_{2} \mathrm{O}(\mathrm{g})+2 \mathrm{CuCl}_{2}(\mathrm{~s}) \rightarrow \mathrm{Cu}_{2} \mathrm{OCl}_{2}(\mathrm{~s})+2 \mathrm{HCl}(\mathrm{g})
$$


Solid feed of $\mathrm{Cu}(\mathrm{II})$ chloride is supplied to the hydrolysis reactor from the dried $\mathrm{CuCl}_{2}$ product of step 2. Water is removed from the aqueous $\mathrm{Cu}(\mathrm{II})$ chloride to produce $\mathrm{CuCl}_{2}$ particles, which are then moved to the hydrolysis unit and reacted with superheated steam to produce solid copper oxychloride and hydrochloric gas.

\subsection{Hydrolysis Experiments (UOIT)}

Experimental studies at UOIT have investigated the optimal operating conditions for the hydrolysis reaction. The main focus of research was to maximize the production of copper oxychloride, while minimizing the steam input. AECL (A. Miller) suggested the concept of mixing steam with nitrogen to minimize the energy requirement of the hydrolysis reaction. The experimental apparatus consisted of the hydrolysis reactor, three zone furnace, nitrogen flow line with a heater, high and low flow superheated steam lines, condensers for cooling the exit gas stream, gas-liquid separator, and a scrubber for non-condensable gases in the downstream region of the hydrolysis reactor (see Fig. 11). The hydrolysis reactor at UOIT is made of quartz glass with an internal diameter of $150 \mathrm{~mm}$ and height of $1.1 \mathrm{~m}$. A ceramic porous distributor is mounted at the bottom of the reactor.

The tubular furnace is made of ceramic fibers containing electrical heating elements. It has three zones with a power rating of $15 \mathrm{~kW}$ and independent temperature control for each zone. The nitrogen line contains flow control valves for low and high flow measurements. The steam line has a steam boiler and superheater with a total power rating of $45 \mathrm{~kW}$ to generate superheated steam at $500{ }^{\circ} \mathrm{C}$ with a maximum steam flow capacity of $30 \mathrm{~kg} / \mathrm{hr}$. An additional steam line is added to generate superheated steam at $<3 \mathrm{~kg} / \mathrm{hr}$ for low flow testing. In the downstream region of the reactor, there are three condensers: one is a quartz condenser and the other two are Pyrex glass condensers $\left(1.2 \mathrm{~m}^{2}\right)$. The quartz condenser is used to lower the reaction gas mixture temperature from 400 to $250^{\circ} \mathrm{C}$ and the other two pyrex condensers are used to condense the reaction gas mixture at maximum steam flow conditions. The non-condensable gases, if any, are separated in a gasliquid separator and scrubbed before exhausting to the atmosphere.

Figures 12a-b show major breakthroughs achieved by the team's experiments over the past year, particularly to significantly reduce the excess steam requirement of hydrolysis to nearly stoichiometric quantities. All three assumptions for the volume of chlorine production $(0.5 \%, 0.18 \%$ and $0 \%)$ produce a steam requirement that drops to near stoichiometric conversion of steam after 80 minutes into the reaction. The measurements were successfully compared against predictive models. The results are very promising because they demonstrate much lower steam to copper chloride ratios than previously reported in past literature [4, 9, 11, 15]. As a result, this lead to significantly higher efficiencies of the $\mathrm{Cu}-\mathrm{Cl}$ cycle than previously reported with higher steam to copper chloride ratios.

The molar fraction of $\mathrm{HCl}$ produced from the hydrolysis reaction in Fig. $12 \mathrm{~b}$ is within $\pm 30 \%$ of the numerically

estimated production of $\mathrm{HCl}$ from the reaction. The change in temperature has no significant effect on the molar 
fraction of $\mathrm{HCl}$ generated. This eliminates the need for an $\mathrm{HCl}-\mathrm{H}_{2} \mathrm{O}$ concentrating process, which is another major breakthrough to improve the efficiency of the $\mathrm{Cu}-\mathrm{Cl}$ cycle. Primarily $\mathrm{CuCl}$ solid particles were formed in the products of the decomposition reaction. High decomposition was observed at $390^{\circ} \mathrm{C}$. Polymorph forms of $\mathrm{CuCl}$ are indicated by two peaks of XRD measurements in Fig. 13. The remaining mass is non-volatile CuO. Chlorine production was measured by a chlorine meter. Although a significant increase in chlorine production was observed in the first 200 mins, beyond a temperature of about $350^{\circ} \mathrm{C}$, no significant increase in chlorine production was observed. A decrease in the chlorine production was observed after about 350 mins. High conversion of $\mathrm{CuCl}_{2}$ to $\mathrm{Cu}_{2} \mathrm{OCl}_{2}$ with minimal chlorine production is desired in the hydrolysis reactor.

\section{Thermolysis Reaction (Step 4)}

\subsection{Copper Oxychloride Decomposition (UOIT)}

The solid copper oxychloride from the hydrolysis reaction is fed into the decomposition process to produce molten $\mathrm{CuCl}$ and oxygen gas $\left(\mathrm{O}_{2}\right)$ at $530^{\circ} \mathrm{C}$. The decomposition reaction is expressed by:

$\mathrm{Cu}_{2} \mathrm{OCl}_{2}(\mathrm{~s})=2 \mathrm{CuCl}$ (molten) $+0.5 \mathrm{O}_{2}$ (gas) $\quad$ (at $530^{\circ} \mathrm{C}$ )

The reactant particles absorb heat from the surrounding $\mathrm{CuCl}$ salt. Other potential undesirable byproducts are $\mathrm{Cl}_{2}$ gas, $\mathrm{HCl}$ gas, and water vapor. Heat is supplied to the reactor by a vertical split-type furnace with three heating zones, independently controlled via SCR power control modules with a PID control interface (see Fig. 14). The heating zones are independently powered for further heat flux control. A secondary section of the reactor chamber is used to channel gases outside in order to maintain a back-pressure within the chamber slightly above atmospheric pressure. This prevents atmospheric gases from contaminating the reactor. A chlorine gas analyzer is used to examine the products from the reactor. An oxygen gas analyzer is also used to examine the products in real time.

Figure 15 illustrates the physical mechanisms of thermochemical decomposition of solid $\mathrm{CuO}^{*} \mathrm{CuCl}_{2}$ particles. Heat is conducted from the molten salt to a particle, raising its temperature to the decomposition reaction point, thereby releasing the products of reaction, molten $\mathrm{CuCl}$ and oxygen gas bubbles from the phase interface. The latent heat for $\mathrm{CuCl}$ melting is absorbed at the transition point of solid $\mathrm{CuO}^{*} \mathrm{CuCl}_{2}$ and molten $\mathrm{CuCl}$ simultaneously. Heat is initially transferred to the molten product, then to the surface of the particle and this causes the phase transition. The phase interface moves inwards and a liquid phase occurs at the outer surface of the particle. The supplied heat must then be conducted through the liquid phase into the moving interface. The solid reactant decomposes and the molten product appears as soon as the high temperature is experienced at the phase interface. This yields a sharp moving interface that separates the solid and liquid regions as indicated in Fig. 15. The latent heat of phase change 
consists of two sources: one involves the melting of $\mathrm{CuCl}$ produced in the reaction, and the other is due to partial evaporation of molten $\mathrm{CuCl}$. Since the $\mathrm{CuCl}$ evaporation is partial, the $\mathrm{CuCl}$ phase change enthalpy caused by partial evaporation of $\mathrm{CuCl}$ is determined by the evaporation latent heat and the production rate of $\mathrm{CuCl}$ vapor. The maximum partial pressure of the $\mathrm{CuCl}$ vapor is the corresponding thermodynamic equilibrium vapor pressure. Therefore, the upper thermodynamic limit of the evaporated amount is determined by both the equilibrium vapor pressure and the oxygen production rate, assuming that the oxygen bubbles are saturated with $\mathrm{CuCl}$ vapor immediately after oxygen is produced. The $\mathrm{CuCl}$ vapor production rate is determined by the $\mathrm{O}_{2}$ production rate, i.e., decomposition rate of reactant, and the evaporation rate of molten $\mathrm{CuCl}$.

Results of the rate of $\mathrm{CuO}^{*} \mathrm{CuCl}_{2}$ solid fraction conversion, $\mathrm{X}$, from experiments conducted with TGA and a vertical reactor are illustrated in Fig. 16. Gravimetric losses started at between 425 and $430^{\circ} \mathrm{C}$. Two chemical reaction pathways were observed in the decomposition, where particles of copper oxychloride are formed from either the decomposition of $\mathrm{CuO}$ (byproduct) or $\mathrm{CuO}^{*} \mathrm{CuCl}_{2}$. The decomposition of $\mathrm{CuCl}_{2}$ is impacted by the presence of $\mathrm{CuO}$ in the reactor. Unreacted $\mathrm{CuO}$ was observed in XRD measurements. The conversion rate of solid with respect to time was accurately predicted by the Avrami-Erofeev equation for kinetic orders of 2 and 3 (see Fig. 16; X refers to solid conversion fraction). Linearity at high rates of conversion was due to additional resistances in the reaction, whereas non-linearity was more pronounced at lower temperatures. Measured conversion of copper oxychloride with respect to temperature was also accurately predicted by the Arrhenius law.

\subsection{Interfacial Diffusion of Rising Bubbles (UOIT)}

During the decomposition of copper oxychloride, oxygen bubbles are released from the solid particles. Rising gas bubbles may absorb $\mathrm{CuCl}$ vapor from the molten salt, thereby requiring further downstream separation of $\mathrm{CuCl}$ from oxygen. Further research was conducted to better understand the processes these mass transfer processes, through simulated experiments of air bubbles rising and absorbing moisture from a water bath in a vertical column (see Fig. 17). Dynamic Studio software was used to capture and analyze the images of bubble formation and dynamics. The images were acquired at a frequency of $91 \mathrm{~Hz}$ in single frame mode. The changes in humidity across the vertical column at different flow rates were measured and correlated in terms of the Reynolds, Sherwood and Eotvos numbers. As expected, higher humidity absorption was associated with higher flow rates. The frequency of bubbles increased

at higher flow rates. The size of bubbles decreased as the flow rates increased. Further studies are underway to investigate detailed correlations involving bubble frequency and size. 
The Eotvos number characterizes the shape of the bubble and it is proportional to the buoyancy force divided by the surface tension force, Eo $=\Delta \rho \mathrm{gL}^{2} / \sigma$, where $\Delta \rho$ is the density change of the two phases and $\sigma$ is the surface tension. The mass transfer coefficient is expressed in terms of the dimensionless Sherwood number, $S h=h_{\text {mass }} L / D_{A B}$, where $h_{\text {mass }}$ is the mass transfer coefficientand $D_{A B}$ is the molecular diffusivity. Based on measured changes of bubble moisture throughout the column, an empirical correlation in Fig. 18 was developed. A slope of 0.0219 was obtained for the correlation. The coefficient of 0.0219 was used for the Reynolds number dependence. The statistical R-squared value of 0.9905 was an indication that the data correlated at this point. The coefficient of Eotvos number was found to be 0.4093 , with an R-squared value of 0.7416 , yielding a correlation as follows:

$$
S h=\operatorname{Re}^{0.0219} E o^{0.4093}
$$

The experimental data and correlation will provide useful information for better understanding of diffusive mass transfer from the liquid bath to rising bubbles in the thermolysis reactor.

\subsection{Heat Recovery from Molten CuCl (UOIT)}

Recent experiments were also performed to recover heat from the exiting molten $\mathrm{CuCl}$ out of the thermolysis reactor. A casting / extrusion method based on a counter-flow heat exchanger configuration was analyzed, wherein molten $\mathrm{CuCl}$ flows inside a tube and coolant flows through the annulus. The cooling process results in the formation of solid $\mathrm{CuCl}$.

A second alternative method was direct contact heat recovery through droplet atomization. Experiments were contacted at UOIT with a thermal imaging camera to measure the temperature of falling molten CuCl droplets through air into a water bath (see Fig. 19). X-ray diffraction analysis of quenched products in Fig. 20 showed that molten CuCl did not react with air or water. The color of solidified $\mathrm{CuCl}$ material was gray. It was observed that copper(I) chloride did not react with water in the absence of oxygen. It was also concluded that the molten droplets of $\mathrm{CuCl}$ did not react with air during the droplet descent. These observations were significant because they confirmed that direct contact heat transfer could be achieved without the added complexity of chemical reactions with oxygen in air or dissolved oxygen bubbles in water.

Steam can be generated from direct quenching of molten $\mathrm{CuCl}$ droplets in water. The steam can either be recycled for other processes within the $\mathrm{Cu}-\mathrm{Cl}$ cycle such as hydrolysis. Molten $\mathrm{CuCl}$ droplets were solidified and disintegrated rapidly into small particle within 2 seconds. These particles can then be readily dissolved in the condensed aqueous $\mathrm{HCl}$ solution from the hydrolysis reactor as the inflow stream to the electrolyzer. 


\section{System Integration of Unit Operations}

\subsection{Integration of Electrolysis and Hydrolysis Steps (AECL)}

New conceptual designs have been proposed by AECL for integration of electrolysis and hydrolysis steps within the $\mathrm{Cu}-\mathrm{Cl}$ cycle. AECL has proposed the method of mixing nitrogen and superheated steam to reduce the steam required by the hydrolysis process. Another important design consideration is the concentration of $\mathrm{CuCl}_{2}$ exiting the electrolytic cell. The output products from the electrolytic cell have been simulated with a quaternary system of $\mathrm{CuCl}_{2}$, $\mathrm{CuCl}, \mathrm{HCl}$, and water. The percentage composition of each product in the output stream in the quaternary system was varied and analyzed to simulate the electrolysis products. Numerical and experimental analyses of crystallization and spray drying processes at UOIT were performed to account for variations in outputs of the electrolysis products. The effects of varying the $\mathrm{HCl}$ concentration and temperature on crystallization processes in the quaternary system were investigated. $\mathrm{HCl}$ liquid was produced separately in the crystallization and spray drying processes for the integrated system. The $\mathrm{CuCl}_{2}$ output from the crystallization and spray drying processes were delivered separately to the hydrolysis reactor to produce $\mathrm{HCl}$ gas.

Solid $\mathrm{CuCl}_{2}$ was supplied into the hydrolysis reactor after drying in the crystallization process. The dried $\mathrm{CuCl}_{2}$ product and water are both inputs into the hydrolysis process, where they are reacted with superheated steam to produce $\mathrm{HCl}$ gas and copper oxychloride. A schematic of the integrated process is shown in Fig. 21. The products of the hydrolysis reaction are solid $\mathrm{Cu}_{2} \mathrm{OCl}_{2}$ and $\mathrm{HCl}$ gas. Water and residual $\mathrm{HCl}$ from the electrolysis cell are preheated in a heat exchanger with condensation heat from the hydrolysis process, in order to reduce the overall energy input into the cycle. The three and four step variations of the $\mathrm{Cu}-\mathrm{Cl}$ cycle differ only with $\mathrm{CuCl}_{2}$ feed to the hydrolysis reactor. Liquid $\mathrm{CuCl}_{2}$ is fed into the reactor for the three step cycle, while solid $\mathrm{CuCl}_{2}$ fed in the four step cycle. The crystallizer or spray dryer is introduced to lower the required heat input for separation of $\mathrm{CuCl}_{2}$ solid from the anolyte mixture. Excess water for the hydrolysis reaction is recycled from the anolyte effluent stream. Nitrogen is mixed with the steam to reduce the steam requirement in the hydrolysis reactor. The effect of electrolyte temperature on the HCl$\mathrm{H}_{2} \mathrm{O}$ system was analyzed for purposes of water recovery from the anolyte effluent stream (see Fig. 22). Excess water was recovered by taking the difference in azeotropic concentration of $\mathrm{HCl}$ and operating conditions. The azeotropic composition of $\mathrm{HCl}$ decreases with temperature.

Lower pressure and temperature in the hydrolysis reactor favour water recovery. Higher pressure reduces the mole fraction of $\mathrm{H}_{2} \mathrm{O}: \mathrm{HCl}$. Additional studies were conducted to determine the variation of azeotropic $\mathrm{HCl}$ concentration with $\mathrm{FeCl}_{3}$ solid concentration. The azeotropic $\mathrm{HCl}$ composition decreases at a higher solid concentration. A conceptual process flow diagram was developed at AECL for high temperature and pressure 
operation. This was developed for both the three and four step cycles, with a crystallizer for $\mathrm{CuCl}_{2}$ solid recovery and a spray dryer to reduce the heat input by waste heat recovery. The HCl-water system with / without a third component for pure water recovery was analysed numerically. It was found that excess water required for the hydrolysis reaction can be recovered from the anolyte effluent by taking the difference in azeotropic $\mathrm{HCl}$ concentration with the operating conditions of the hydrolysis reactor.

\subsection{Integration of Hydrogen and Nuclear Plants (UOIT, AECL)}

UOIT is collaborating with AECL on various plant configurations for co-generation of electricity and hydrogen. SCWR (Super-Critical Water Reactor) is the Generation IV nuclear reactor under development by AECL that will operate at temperatures up to $625^{\circ} \mathrm{C}$ and facilitate the thermochemical production of hydrogen with the $\mathrm{Cu}$ $\mathrm{Cl}$ cycle. Integrating an SCWR with a $\mathrm{Cu}-\mathrm{Cl}$ plant requires an interface and intermediate heat exchanger between the nuclear and hydrogen plant. A fraction of the high temperature SCW coolant is diverted to the intermediate heat exchanger, where it exchanges heat with an intermediate fluid (such as steam or helium). It is then returned to a location on the feedwater heating line or reactor inlet. To link the $\mathrm{Cu}-\mathrm{Cl}$ cycle with the SCWR, the HX would be in a location where the inlet coolant would be at temperatures exceeding the maximum temperature requirement of the $\mathrm{Cu}$ $\mathrm{Cl}$ cycle, approximately $530^{\circ} \mathrm{C}$.

Figure 23 illustrates sample results of SCW (supercritical water) and SHS (supercritical steam) temperature and heat transfer coefficients in a double pipe intermediate heat exchanger. Sub-cooled water from the feedwater system enters the reactor at $25 \mathrm{MPa}$ and $350^{\circ} \mathrm{C}$. As the coolant is heated through the fuel channels, it passes through the pseudocritical temperature of $384.9^{\circ} \mathrm{C}$ (at $25 \mathrm{MPa}$ ), and exits the reactor at $625^{\circ} \mathrm{C}$. At these conditions the coolant is capable of providing the entire thermal energy source for the $\mathrm{Cu}-\mathrm{Cl}$ cycle. The heat exchanger is integrated at the reactor outlet location. After heating of SHS through the heat exchanger, the SCW coolant would ideally exist at a sub-critical state and be re-integrated back into the SCWR plant coolant loop. Suitable re-entry locations on the nuclear power plant are required, as it is preferred that the SCW flow exits the heat exchanger above the pseudocritical point. Pressure drop analysis has indicated significant pressure losses for SHS flows. Higher SCW outlet temperatures and lower pipe lengths were found to be better suited for improved heat transfer.

\subsection{Integration of Cu-Cl Cycle with Renewable Energy Systems (UOIT)}

Past studies were performed by Orhan et al. [24, 27, 31] to investigate the integration of Cu-Cl cycle with various renewable energy systems and make comparisons between different options, including cost comparisons and advantages / disadvantages of each system. Instead of a nuclear plant, a solar thermal plant could be linked to the Cu- 
Cl cycle with existing commercial technology to provide heat and electricity for the cycle. This system has drawbacks of no backup energy source (during periods of no or low sunlight) and controlling the load imbalance. An integrated nuclear / solar energy system was analyzed by using the combined solar radiation and nuclear power as dual sources of heat and electricity for the $\mathrm{Cu}-\mathrm{Cl}$ cycle. This configuration yields constant heat input to the $\mathrm{Cu}-\mathrm{Cl}$ cycle. Another investigated option was a wind-solar based $\mathrm{Cu}-\mathrm{Cl}$ cycle. The wind power generation system could be incorporated with the solar plant and linked to the $\mathrm{Cu}-\mathrm{Cl}$ cycle and energy storage, to ensure a steady supply of heat and electricity. Combined wind and solar energy systems are currently in operation at the Desert Research Institute in Reno, Nevada, as well as the Hydrogen Research Institute at the Universite du Quebec, Trois Rivieres. These independently operating systems use solar radiation and wind energy together to generate hydrogen. The demonstration systems generate hydrogen in a relatively small capacity, with a compressed hydrogen storage system. Another renewable-based Cu-Cl hydrogen production option is combined geothermal electricity generation and solar heating, which is integrated with the $\mathrm{Cu}-\mathrm{Cl}$ cycle. A disadvantage of geothermal energy sources is generally low temperature operating conditions that cannot satisfy the $\mathrm{Cu}-\mathrm{Cl}$ cycle thermal requirements. But, the system can generate electricity that is needed for the $\mathrm{Cu}-$ $\mathrm{Cl}$ cycle. The final system that was examined was integrated biomass gasification and the $\mathrm{Cu}-\mathrm{Cl}$ cycle. In this system, heat provided by the syngas cooling section of an Integrated Gasification Combined Cycle (IGCC) plant, previously used for low-pressure steam generation, was used as the major heat input for the $\mathrm{Cu}-\mathrm{Cl}$ cycle. The produced oxygen from the $\mathrm{Cu}-\mathrm{Cl}$ cycle was used instead of input air in the gasification process to improve the combustion efficiency, increase the hydrogen content of produced syngas, and reduce the $\mathrm{NO}_{\mathrm{x}}$ and $\mathrm{CO}_{2}$ emissions.

\section{Advanced Materials}

\subsection{Electrolysis Anode Materials (UOIT)}

Improvements to anode materials in the $\mathrm{CuCl} / \mathrm{HCl}$ electrolysis cell have been investigated extensively by Easton and co-workers [64 - 67]. Carbon electrodes have been examined to replace the $\mathrm{Pt} / \mathrm{C}$ anodes, as the presence of Pt does not improve anodic activity [65]. Ceramic carbon electrodes (CCE) with a three-dimensional porous structure composed of a high surface area carbon black were bound together by an aminosilane-based silicate network. The amine groups on the aminosilicate were protonated under cell operating conditions and therefore assisted in the transport of anionic Cu species [64]. These CCE layers have been shown to outperform bare CFP (carbon fibre paper) or graphite plates at $\mathrm{CuCl}$ concentrations up to $0.5 \mathrm{M}$ in half cell experiments [64].

Other recent CCE developments has focused on the modification of the aminosilane precursors. CCEs were prepared from three different aminosilanes: 3-aminopropyl-trimethoxysilane, N-[3-(trimethoxysilyl)propyl]- 
ethylenediamine, and N'-[3-(Trimethoxysilyl)-propyl] diethylenetriamine, referred hereafter as N1, N2, and N3, respectively. This series employs progressively longer side chains that contain an increased number of amine groups [66]. They were chosen since a higher density of anion conductors was expected to lead to enhanced anionic transport and electrode performance. Half-cell electrochemical impedance spectroscopy (EIS) measurements were performed in the absence of $\mathrm{Cu}(1.5 \mathrm{M} \mathrm{HCl}$ only) and shown in Fig. 24. Edge and Easton [67] have recently demonstrated how these EIS measurements enable clear assessment of surface area and ion transport properties. The electrode resistance decreases as the side chain length and number of amine groups are increased. However, 2N-based CCEs have the largest available surface areas based upon the maximum specific capacitance (see Fig. 25b), which indicates these layers have a better combination of high surface area and ion conductivity.

CCE materials have also been evaluated in a full electrolysis cell. Figure 25a illustrates the experimental apparatus. Three samples with varying wt\% PAPS (1N-based CCE) were tested. Samples were spray coated onto bare CFP with a loading of $4.25 \mathrm{mg} / \mathrm{cm}^{2} \pm 1 \mathrm{mg} / \mathrm{cm}^{2}$. Nafion 115 was used as the proton conductive membrane and a standard Pt-based cathode was used in all cases. The electrolysis cell performance was measured at $25{ }^{\circ} \mathrm{C}$ using flowing $0.2 \mathrm{M} \mathrm{CuCl}$ in $2 \mathrm{M} \mathrm{HCl}$ as the anolyte and flowing water as the catholyte [12]. Figure 25(b) shows that the performance with $44 \mathrm{wt} \%$ and $53 \mathrm{wt} \%$ PAPS was similar at low potentials. The $53 \mathrm{wt} \%$ samples performed better at higher current densities. The performance achieved with $62 \mathrm{wt} \%$ was inferior over the entire range. EIS measurements were also performed on the anode in the full cell configuration by using an anolyte of $1.5 \mathrm{M} \mathrm{HCl}(\mathrm{no} \mathrm{Cu})$ and employing $\mathrm{H}_{2}$ gas at the cathode (to serve as a reference electrode). The EIS capacitance plots are shown in Figure 25c, which shows that even though all three CCE anodes have similar active areas, $53 \mathrm{wt} \%$ PAPS has the least resistance, thereby leading to higher performance.

\subsection{Corrosion Resistance of Coatings in Molten CuCl (UOIT and University of Toronto)}

Thermal spray coatings were developed and tests for corrosion resistance to molten $\mathrm{CuCl}$, particularly by characterizing the coatings and testing their integrity in molten $\mathrm{CuCl}$. The original coating materials chosen for exposure to molten $\mathrm{CuCl}$ included zirconia and alumina coatings on Inconel (nickel alloy) and stainless steel (ferrous alloy) base materials. Good corrosion resistance of the underlying metals is needed in case the coating is degraded or damaged, exposing the underlying metal to corrosive conditions. The metal should be sufficiently corrosion resistant to permit detection of a damaged coating before catastrophic failure occurs and thereby permit repairs to the coating to be performed instead of replacing a component. With the high operating temperature of molten $\mathrm{CuCl}, 500{ }^{\circ} \mathrm{C}$, a metallic inter-layer coating was considered as a means of minimizing thermal expansion effects caused by a ceramic coating on a metal. Diamalloy, a high nickel-chrome material, was selected for the application. 
The experimental apparatus consists of an immersion cell set-up, a gas cylinder (1) that feeds the test cell (3) containing the molten $\mathrm{CuCl}$ and test specimen with inert gas, a heater (2) to melt the $\mathrm{CuCl}$ and control the temperature of the experiments, as well as an exhaust/scrubber system $(4,5)$ to control the release of noxious fumes (Figure 26) [7]. The immersion vessel is made of quartz and has three input tubes. Two tubes are used to allow gas to be purged into/out of the system. The other tube is used for the thermocouples to monitor the working temperature inside the immersion vessel. The cold-trap vessel cools the hot exhaust gas from the immersion vessel and prevents hot gas from entering the scrubber. It is also serves as a vacuum break to prevent the water siphoning from the scrubber to the immersion vessel. The scrubber contains a solution of sodium bicarbonate in water that reacts with any residual chlorine gas to produce salt and carbon dioxide, neutralizing the gas which is then safe to exhaust into the fume hood.

Characterization of the corrosion behavior of the surfaces was performed by scanning electron microscopy (SEM) and energy dispersive X-ray (EDX) examination of the surface. This includes ex-situ imaging of the surface and examination to determine the physical breakdown, loss of integrity, and surface restructuring. Also, electrochemical impedance spectroscopy (EIS/AC impedance) examined the integrity of the film, as well as chemical reactivity of the surfaces, interfacial breakdown, and solution penetration.

Figure 27a shows an optical image (top left) of an Inconel 625 specimen following 4 days exposure to molten $\mathrm{CuCl}$ at $500{ }^{\circ} \mathrm{C}$. The image on the lower left is an SEM image of spot A taken at 250x magnification. The bright spots on the map represent high concentrations of an element at each location on the image. The electron image is shown. For Inconel, nickel and chromium are the predominant elements in the metal and although the surface is rough, most of the corroded surface remained predominately nickel and chromium, possibly an oxide layer based on the roughness of the surface. However, there are dark areas indicating an absence of nickel and chromium, which correspond to bright areas on the copper map. Copper is not present in high concentration in the base alloy. The absence of nickel and chromium suggests that there is a deposit of copper formed on the surface. The chloride map does not show a correlation between the large copper deposits and the chloride spots indicating that the copper is elemental copper. The formation of such a deposit suggests that the $\mathrm{Cu}+$ ion of $\mathrm{CuCl}$ was reduced to copper metal, driving the oxidation of the Inconel.

Figure 27b shows the corrosion of a super-austenitic stainless steel, AL-6XN. As with the previous results, an optical image (top left) is shown for the metal coupon following exposure to molten $\mathrm{CuCl}$ at $500{ }^{\circ} \mathrm{C}$ for 4 days, with an SEM and EDX image of area A, a spot below the surface of the liquid. The EDX maps shows nickel, chromium, and for stainless steel, iron. A copper containing area is seen in the image. The particles on the surface are mostly copper deposits. Chloride was found on the surface, but not in association with the copper. It appears to be associated more with the iron than nickel, suggesting that the corrosion process may have produced an iron chloride layer. 
Additional tests were performed on stainless steel with a Diamalloy coating, as well as Inconel with a Y stabilized zirconia coating. For the AL6XN stainless steel specimen with a high-Ni Diamalloy coating, the analysis showed that little corrosion occurred, possibly indicating that the film was intact through most of the immersion period. The stainless steel coupon with both the Diamalloy inner coating and an Alumina outer coating was blackened following exposure to molten $\mathrm{CuCl}$ for 4 days at $500{ }^{\circ} \mathrm{C}$. No copper deposits were identified, and chloride was also evenly distributed over the surface. The aluminum map showed the surface was coated, but with a relatively thin layer, suggested by a low density of spots. This may indicate that the alumina film was thinned during exposure and/or the metal elements (especially chromium) migrated into the alumina layer. The results may indicate that nickel was depleted and dissolved, passing through the alumina layer into the $\mathrm{CuCl}$ liquid. Evidence of corrosion was also observed for Inconel with a Y stabilized zirconia coating. The EDX maps showed the coating and underlying nickel and chrome of Inconel. There was no clear deposition of copper, or accumulation of chloride, although there appeared to be less chloride on the coating than the metal.

Overall, it was found that zirconia coatings performed better than alumina. Stainless steel showed poorer corrosion resistance after the coating disbonded. Further research is underway to examine coating methods to minimize disbonding and penetration of molten $\mathrm{CuCl}$ into the coating. The team is also investigating the presence and evolution of microvoids in the coated specimens. The goal is to establish superior corrosion performance in high temperature $\mathrm{CuCl}$ environments.

\section{Conclusions}

Recent advances in the thermochemical $\mathrm{Cu}-\mathrm{Cl}$ cycle for nuclear hydrogen production by an international consortium have been presented in this paper. Experimental and numerical results from the various research groups were highlighted. Efficient long-term performance of the $\mathrm{CuCl} / \mathrm{HCl}$ electrolyzer has been successfully demonstrated, with minimal copper crossover. A major reduction in the excess steam requirement to about 3 times the stoichiometric quantity has been achieved for the hydrolysis reactor. Also, the exiting steam to $\mathrm{HCl}$ ratio is sufficient to allow the condensed mixture to be supplied directly to the electrolyzer, without an intermediate energy intensive process of gas phase separation. For heat recovery of molten $\mathrm{CuCl}$ from the thermolysis reactor, it was shown that no chemical reaction occurs in direct contact heat transfer between molten $\mathrm{CuCl}$ droplets, air and water. These advances and better understanding of the electrolysis, hydrolysis, heat recovery, materials and other processes will significantly improve the overall efficiency of the $\mathrm{Cu}-\mathrm{Cl}$ cycle.

\section{Acknowledgements}


Support of this research from Atomic Energy of Canada Limited, Ontario Research Excellence Fund, Natural Sciences and Engineering Research Council of Canada, University Network of Excellence in Nuclear Engineering (UNENE) and the Canada Research Chairs program are gratefully acknowledged.

\section{$\underline{\text { References }}$}

[1] Naterer, G. F., Sophia, S., Stolberg, L., Lewis, M., Wang, Z., Daggupati, V., Gabriel, K., Dincer, I., Rosen, M. A., Spekkens, P., Lvov, L., Fowler, M., Tremaine, P., Mostaghimi, J., Easton, E. B., Trevani, L., Rizvi, G., Ikeda, B. M., Kaye, M. H., Lu, L., Pioro, I., Smith, W. R., Secnik, E., Jiang, J., Avsec, J., “Canada’s Program on Nuclear Hydrogen Production and the Thermochemical Cu-Cl Cycle”, International Journal of Hydrogen Energy, vol. 35, pp. 10905 - 10926, 2010

[2] Syed, F., Fowler, M., Wan, D., Maniyali, Y., “An energy demand model for a fleet of plug-in fuel cell vehicles and commercial building interfaced with a clean energy hub”, International Journal of Hydrogen Energy, vol. 35, no. 10, pp. $5154-5163,2010$

[3] McQuillan, B. W., Brown, L. C., Besenbruch, G. E., Tolman, R., Cramer, T., Russ, B. E., Vermillion, B. A., Earl, B., Hsieh, H. T., Chen, Y., Kwan, K., Diver, R., Siegal, N., Weimer, A., Perkins, C., Lewandowski, A., “High Efficiency Generation of Hydrogen Fuels Using Solar Thermochemical Splitting of Water: Annual Report”, GAA24972, General Atomics, San Diego, CA, 2002

[4] Lewis M., Taylor, A., "High Temperature Thermochemical Processes”, DOE Hydrogen Program, Annual Progress Report, Washington, DC, pp. 182 - 185, 2006

[5] Sakurai M, Nakajima H, Amir R, Onuki K, Shimizu S., "Experimental Study on Side-Reaction Occurrence Condition in the Iodine-Sulfur Thermochemical Hydrogen Production Process”, International Journal of Hydrogen Energy, vol. 23, pp. $613-619,2000$

[6] Schultz, K., “Thermochemical Production of Hydrogen from Solar and Nuclear Energy”, Technical Report for the Stanford Global Climate and Energy Project, General Atomics, San Diego, CA, 2003

[7] Sadhankar, R. R. Li, J., Li, H., Ryland, D. K., Suppiah, S., "Future Hydrogen Production Using Nuclear Reactors”, EIC Climate Change Technology Conference, May 10 - 12, 2006, Ottawa, Ontario

[8] Carty, R. H., Mazumder, M., Schreider, J. D., Panborn, J. B., “Thermochemical Hydrogen Production”, vol. 1, Gas Research Institute for the Institute of Gas Technology, GRI Report 80-0023, Chicago, IL 60616, 1981

[9] Lewis, M. A., Serban, M., Basco, J. K., "Hydrogen Production at $<550^{\circ} \mathrm{C}$ Using a Low Temperature Thermochemical Cycle”, GLOBAL 2003 Conference, pp. 1492-8, New Orleans, USA, November 16-20, 2003 
[10] Stolberg, L., "Electrolysis Cell for the Conversion of Cuprous Chloride in Hydrochloric Acid to Cupric Chloride and Hydrogen Gas”, U.S. Patent No. 0051469, 2010

[11] Suppiah, S., Naterer, G. F., Lewis, M., Trevani, L., Easton, B., Dincer, I., Gabriel, K., Smith, W., Ikeda, B., Rizvi, G. et al., Thermo-Mechanical Design of Nuclear-Based Hydrogen Production, ORF Workshop on NuclearBased Thermochemical Hydrogen Production, February, 2011, Oshawa, Ontario

[12] Balashov, V. N., Schatz, R. S., Chalkova, E., Akinfiev, N. N., Fedkin, M. V., and Lvov, S. N., ”CuCl Electrolysis for Hydrogen Production in the Cu-Cl Thermochemical Cycle”, Journal of the Electrochemical Society, vol. 158, pp. 266-275, 2011

[13] Daggupati, V. N., Naterer, G. F., Gabriel, K. S., Gravelsins, R. J., Wang, Z. L., "Effects of Atomization Conditions and Flow Rates on Spray Drying for Cupric Chloride Particle Formation”, International Journal of Hydrogen Energy, vol. 36, pp. 11353 - 11359, 2011

[14] Slowikowski, M., Naterer, G. F., Daggupati, V., "Experimental Cupric Chloride Drying Studies of Spray Atomization”, 3nd International Conference on Hydrogen Production, Thessaloniki, Greece, June 19 - 22, 2011

[15] Lewis, M., Masin J., Vilim, R., Serban, M., “Development of the Low Temperature Cu-Cl Thermochemical Cycle”, International Congress on Advances in Nuclear Power Plants, May 15 - 19, 2005, Seoul, Korea

[16] Daggupati, V. N., Naterer, G. F., Dincer, I., “Convective Heat Transfer and Solid Conversion of Reacting Particles in a Copper (II) Chloride Fluidized Bed”, Chemical Engineering Science, vol. 66, pp. 460 - 468, 2011

[17] Pope, K., Daggupati, V., Naterer, G. F., "Experimental Study of Reaction Rates and Steam Consumption in a Copper (II) Chloride Fluidized Bed Reactor”, 3nd International Conference on Hydrogen Production, Thessaloniki, Greece, June 19 - 22, 2011

[18] Daggupati, V., Pope, K., Naterer, G. F., Gabriel, K., Wang, Z., “Conversion of Solid Cupric Chloride in a Fluidized Bed Hydrolysis Reactor”, 3nd International Conference on Hydrogen Production, Thessaloniki, Greece, June 19 - 22, 2011

[19] Daggupati, V. N., Naterer, G. F., Gabriel, K. S., Gravelsins, R. J., Wang, Z. L., “Solid Particle Decomposition and Hydrolysis Reaction Kinetics in $\mathrm{Cu}-\mathrm{Cl}$ Thermochemical Hydrogen Production”, International Journal of Hydrogen Energy, vol. 35, pp. 4877 - 4882, 2010

[20] Serban, M., Lewis, M. A., Basco, J. K., “Kinetic Study of the Hydrogen and Oxygen Production Reactions in the Copper-Chloride Thermochemical Cycle”, AIChE 2004 Spring National Meeting, New Orleans, LA, April 25-29, 2004

[21] Ghandehariun, S., Rosen, M. A., Naterer, G. F., Wang, Z., “Comparison of Molten Salt Heat Recovery Options in the Cu-Cl Cycle of Hydrogen Production” (in press), International Journal of Hydrogen Energy, 2011 
[22] Ghandehariun, S., Naterer, G. F., Rosen, M. A., "Molten Salt Heat Recovery and Solidification Phase Change in the Copper-Chlorine Cycle”, 3nd International Conference on Hydrogen Production, Thessaloniki, Greece, June 19 $-22,2011$

[23] Ferrandon, M. S., Lewis, M. A., Tatterson, D. F., Nankanic, R. V., Kumarc, M., Wedgewood, L. E., Nitsche, L. C., "The Hybrid Cu-Cl Thermochemical Cycle. I. Conceptual Process Design and H2A Cost Analysis. II. Limiting the Formation of CuCl During Hydrolysis”, NHA Annual Hydrogen Conference, Sacramento Convention Center, CA, March 30 - April 3, 2008

[24] Orhan, M. F., “Analysis, Design and Optimization of Nuclear-Based Hydrogen Production with CopperChlorine Thermochemical Cycles”, PhD Dissertation, Faculty of Engineering and Applied Science, University of Ontario Institute of Technology, Oshawa, Ontario, April, 2011

[25] Wang, Z. L., Naterer, G. F., Gabriel, K. S., Gravelsins, R., Daggupati, V. N., "New Cu-Cl Thermochemical Cycle for Hydrogen Production with Reduced Excess Steam Requirements”, International Journal of Green Energy, vol. 6, pp. 616 - 626, 2009

[26] McDougall, R., Nokleby, S. B., “Multi-Objective Parallel Asynchronous Particle Swarm Optimization for Engineering Design Problems”, ASME International Design Engineering Technical Conferences, August 30 September 2, 2009, San Diego, CA

[27] Orhan, M. F., Dincer, I., Rosen, M. A., "Design of systems for hydrogen production based on the Cu-Cl thermochemical water decomposition cycle: Configurations and performance”, International Journal of Hydrogen Energy, vol. 36, pp. 11309 - 11320, 2011

[28] Orhan, M. F., Dincer, I., Rosen, M. A., "Exergy analysis of heat exchangers in the copper-chlorine thermochemical cycle to enhance thermal effectiveness and cycle efficiency”, 5th International Energy Symposium and Exhibition (IEESE-5), Denizli, Turkey, June 27 - 30, 2010

[29] Orhan, M.., Dincer, I., Rosen, M., “Exergoeconomic analysis of a thermochemical copper-chlorine cycle for hydrogen production using specific exergy cost (SPECO) method”, Thermochimica Acta, vol. 497, pp. 60 - 66, 2010 [30] Orhan, M. F., Dincer, I., Rosen, M. A., “An exergy-cost-energy-mass analysis of a hybrid copper-chlorine thermochemical cycle for hydrogen production”, International Journal of Hydrogen Energy, vol. 35, pp. 4831 - 4838 , 2010

[31] Orhan, M. F., Dincer, I., Naterer, G. F., Rosen, M. A., “Coupling of copper-chlorine hybrid thermochemical water splitting cycle with a desalination plant for hydrogen production from nuclear energy”, International Journal of Hydrogen Energy, vol. 35, pp. 1560-1574, 2010 
[32] Orhan, M. F., Dincer, I., Rosen, M. A., "Efficiency analysis of a hybrid copper-chlorine (Cu-Cl) cycle for nuclear-based hydrogen production”, Chemical Engineering Journal, vol. 155, pp. 132-137, 2009

[33] Ozbilen, A., Dincer I., Rosen, M.A. “A comparative life cycle analysis of hydrogen production via thermochemical water splitting using a $\mathrm{Cu}-\mathrm{Cl}$ cycle”, International Conference on Hydrogen Production, Istanbul, Turkey, June 16 - 18, 2010

[34] Ozbilen, A., Dincer I., Rosen, M. A., “A comparative life cycle analysis of hydrogen production via thermochemical water splitting using a Cu-Cl cycle”, International Journal of Hydrogen Energy, vol. 36, pp. 11321 11327, 2011

[35] Solli C., Stromman A. H., Hertwish E. G., "Fission or Fossil: Life cycle assessment of hydrogen production”, Proceedings of the IEEE, vol. 94, no. 10, 2006

[36] Utgikar V., Thiesen T., "Life cycle assessment of high temperature electrolysis for hydrogen production via nuclear energy”, International Journal of Hydrogen Energy, vol. 31, pp. 939 - 944, 2006

[37] Goedkoop M., Demmers M., Collignon M., “Eco-indicator 95 Manual for Designers”, National Reuse of Waste Research Programme, Netherlands, 1996

[38] Spekkens P, Naterer GF, Gravelsins R., Wang, F, Secnik, E, Personal Communication, Ontario Power Generation, Pickering, Ontario, Canada, March, 2010

[39] Zamfirescu, C., Dincer, I., Naterer, G. F., "Performance Evaluation of Organic and Titanium Based Working Fluids for High Temperature Heat Pumps”, Thermochimica Acta, vol. 496, pp. 18 - 25, 2009

[40] Naterer, G. F., "Second Law Viability of Upgrading Industrial Waste Heat for Thermochemical Hydrogen Production”, International Journal of Hydrogen Energy, vol. 33, 6037 - 6045, 2008

[41] Granovskii, M., Dincer, I., Rosen, M. A., Pioro, I., “Thermodynamic Analysis of the Use of a Chemical Heat Pump to Link a Super-Critical Water-Cooled Nuclear Reactor and a Thermochemical Water-Splitting Cycle for Hydrogen Production”, JSME Journal of Power and Energy Systems, vol. 2, pp. 756 - 767, 2008

[42] Zamfirescu, C., Naterer, G. F., Dincer, I., "Vapor Compression CuCl Heat Pump Integrated with a Thermochemical Water Splitting Plant”, Thermochimica Acta, vol. 512, pp. 40 - 48, 2011

[43] Zamfirescu, C., Naterer, G. F., Dincer, I., "Upgrading of Waste Heat for Combined Power and Hydrogen Production with Nuclear Reactors”, ASME Journal of Engineering for Gas Turbines and Power, vol. 132, no. 10, pp. 102911 - 102919, October, 2010

[44] Ghandehariun, S., Rosen, M. A., Naterer, G. F., Wang, Z., "Pinch Analysis for Effective Heat Recovery in the Cu-Cl Cycle of Hydrogen Production”, 3nd International Conference on Hydrogen Production, Thessaloniki, Greece, June 19 - 22, 2011 
[45] Lukomski, A., Pioro, I., Gabriel, K., "Hydrogen Production Using Process Heat from an SCW NPP via a Double-Pipe Heat Exchanger”, 5th International Symposium on SCWR (ISSCWR-5), Vancouver, BC, Canada, March $13-16,2011$

[46] Mokry, S., Lukomski, A., Gabriel, K., Pioro, I., Naterer, G. F., “Thermalhydraulic and Heat Transfer Correlations for an Intermediate Heat Exchanger Linking a Supercritical Water-Cooled Reactor and Copper-Chlorine Cycle of Hydrogen Production”, 3nd International Conference on Hydrogen Production, Thessaloniki, Greece, June $19-22,2011$

[47] Lukomski, A., Pioro, I., Gabriel, K., “Aspects of Hydrogen Production Using a SuperCritical Water-Cooled Nuclear Reactor", 31st Annual Conference of Canadian Nuclear Society, Montreal, QC, Canada, May 24 - 27, 2010 [48] Lukomski, A., Pioro, I., Gabriel, K., “Aspects on Hydrogen Co-Generation Using a Thermochemical Cycle Linked to a Supercritical Water-Cooled Nuclear Reactor”, 2nd Canada-China Joint Workshop on Supercritical WaterCooled Reactors (CCSC-2010), Toronto, Ontario, April 25-28, 2010

[49] Naidin, M., Mokry, S., Monichan, R., Chophla, K., Pioro, I., Naterer, G. and Gabriel, K. 2009. Thermodynamic Analysis of SCW NPP Cycles with Thermo-Chemical Co-Generation of Hydrogen, Proc. of the International Conference on Hydrogen Production-2009 (ICH2P-09), Oshawa, Ontario, Canada, May, Paper No. ICH2P-GP163, 2009

[50] Sun, P. W., Jiang, J., "Thermal-hydraulic Modeling of CANDU-SCWR and Linear Dynamic Model Development”, 18th International Conference on Nuclear Engineering (ICONE), Xi'an, China, May 17 - 21, 2010

[51] Sun, P. W., Jiang, J., Shan. J. Q., “Construction of dynamic model of CANDU-SCWR using moving boundary method”, Nuclear Engineering and Design, vol. 241, no. 5, pp. 1701 - 1714, 2011

[52] Ma, J., Jiang, J., “Detection and Identification of Faults in NPP Instruments using Kernel Principal Component Analysis”, ASME Journal of Engineering for Gas Turbines and Power, vol. 134, no. 3, pp. 032901 - 032906, 2012

[53] Al-Dabbagh, A. W., Lu, L., "Design and Reliability Assessment of Control Systems for a Nuclear-based Hydrogen Production Plant with Copper-Chlorine Thermochemical Cycle”, International Journal of Hydrogen Energy, vol. 35, pp. 966 - 977, 2010

[54] Al-Dabbagh, A. W., Lu, L., "Dynamic Flowgraph Modeling of Process and Control Systems of a Nuclearbased Hydrogen Production Plant”, International Journal of Hydrogen Energy, vol. 35, pp. 9569 - 9580, 2010

[55] Al-Dabbagh, A. W., Lu, L., “A Distributed Control System Design for Nuclear-based Hydrogen Production with Copper-chlorine Thermochemical Cycle”, 30th Annual Conference of the Canadian Nuclear Society, May 31 June 3, 2009, Calgary, AB 
[56] Moucka, F., Lisal, M., Smith, W. R., Jirsak, J., Skvor, J., Nezbeda, I., "Molecular-level Simulation of Electrolyte Systems: Molecular-level Modeling of Aqueous Electrolyte Thermodynamics”, 60th Canadian Chemical Engineering Conference, Saskatoon, October 24 - 27, 2010

[57] Jirsak, J., Skvor, J., Smith, W. R., Nezbeda, I., "Molecular-level simulation of electrolyte system solubility and chemical speciation”, DECHEMA Workshop on Molecular Modeling and Simulation for Industrial Applications, Wurzburg, Germany, Mar. 22-23, 2010

[58] Trevani, L., Ehlerova, J., Sedlbauer, J., Tremaine, P. R., “Complexation in the Cu(II)-LiCl-H2O system at temperatures to $423 \mathrm{~K}$ by UV-Visible spectroscopy”, International Journal of Hydrogen Energy, vol. 35, pp. 4893 4900, 2010

[59] Ikeda, B. M., Kaye, M. H., “Thermodynamic Properties in the Cu-Cl-O-H System”, 7th International Conference on Nuclear and Radiochemistry, Budapest, Hungary, August 2008

[60] Trevani, L., “The Copper-Chloride Cycle: Synthesis and Characterization of Copper Oxychloride”, Hydrogen and Fuel Cells International Conference and Exhibition, Vancouver, BC, May 15 - 18, 2011

[61] Avsec, J., Naterer, G. F., Predin, A., “Calculation of Thermodynamic Properties for Hydrochloric and Copper Compounds in a Hydrogen Production Process”, Journal of Energy Technology, vol. 2, pp. 47 - 64, 2009

[62] Avsec, J., Naterer, G. F., Predin, A., "Calculation of Thermodynamic Properties for Components in a Hydrogen Production Process”, International Conference on Energy Technology and Climate Change, July 1 - 3, 2009, Velenje, Slovenia

[63] Ferrandon, M., Lewis, M., Trevani, L., Daggupati, V., Wang, Z., Naterer, G. F., “Using XANES and XAFS for Kinetic and Mechanistic Data of the Decomposition of $\mathrm{CuCl}_{2}$ and $\mathrm{Cu}_{2} \mathrm{OCl}_{2}$ and the Hydrolysis of $\mathrm{CuCl}_{2}$ in the Cu-Cl Cycle of Hydrogen Production”, Hydrogen and Fuel Cells International Conference and Exhibition, Vancouver, BC, May $15-18,2011$

[64] Ranganathan, S., Easton, E. B., "High performance ceramic carbon electrodes-based anodes for use in the CuCl thermochemical cycle for hydrogen production”, International Journal of Hydrogen Energy, vol. 35, pp. 1001 1007,2010

[65] Naterer, G. F., Suppiah, S., Lewis, M., Gabriel, K., Dincer, I., Rosen, M. A., Fowler, M., Rizvi, G., Easton, E. B., Ikeda, B. M., Kaye, M., Lu, L., Pioro, I., Spekkens, P., Tremaine, P., Mostaghimi, J., Avsec, J., Jiang, J., “Recent Canadian Advances in Nuclear-Based Hydrogen Production and the Thermochemical Cu-Cl Cycle”, International Journal of Hydrogen Energy, vol. 34, pp. 2901 - 2917, 2009

[66] Pauric, A. D., Pedersen, A. W., Andrusiak, T., Easton, E. B., “A Surface Modification Route to Non-Precious Metal Fuel Cell Catalysts”, Journal of the Electrochemical Society, vol. 157, pp. 370 - 375, 2010 
[67] Edge, P. S., Easton, E. B., "Evaluation of Anode Electrode Materials for $\mathrm{Cu}-\mathrm{Cl} / \mathrm{HCl}$ Electrolyzers for Hydrogen Production”, ECS Transactions, vol. 41, no. 31, pp. 111 - 120, 2012

[68] Miller, A. I., Duffey, R. B., "Sustainable and Economic Hydrogen Co-generation from Nuclear Energy in Competitive Power Markets”, International Energy Workshop, Laxenburg, Austria, June 24 - 26, 2003

[69] Miller, A. I., “Electrochemical Production of Hydrogen by Nuclear Energy”, Nuclear Production of Hydrogen - Technologies and Perspectives for Global Deployment, Chapter 4, American Nuclear Society, La Grange Park, Illinois, 2004

[70] Naterer, G. F., Fowler, M., Cotton, J., Gabriel, K., "Synergistic Roles of Off-peak Electrolysis and Thermochemical Production of Hydrogen from Nuclear Energy in Canada”, International Journal of Hydrogen Energy, vol. 33, pp. 6849 - 6857, 2008

[71] Wang, Z., Naterer, G. F., “Greenhouse Gas Reduction of Oil Sands Upgrading and Extraction Operations with Thermochemical Hydrogen Production”, International Journal of Hydrogen Energy, vol. 35, pp. 11816 - 11828, 2010 [72] Hajimiragha, A., Fowler, M. W., Cañizares, C. A., "Hydrogen economy transition in Ontario - Canada considering the electricity grid constraints”, International Journal of Hydrogen Energy, vol. 34, pp. 5275-5293, 2009 [73] Kantor, I., Fowler, M.W., Hajimiragha, A., Elkamel, A., “Air quality and environmental impacts of alternative vehicle technologies in Ontario, Canada”, International Journal of Hydrogen Energy, vol. 35, no. 10, pp. 5145-5153, 2010

[74] Miller, A., “Hydrail: An adaptable, low-cost alternative to electrification”, Paper 4-205-4, Hydrogen and Fuel Cells Conference, Vancouver, British Columbia, April 29 - May 2, 2007

[75] Haseli, Y., Naterer, G. F., Dincer, I., “Comparative Assessment of Greenhouse Gas Mitigation of Hydrogen Passenger Trains", International Journal of Hydrogen Energy, vol. 33, pp. 1788 - 1796, 2008

[76] Marin, G., Naterer, G. F., Gabriel, K., “Rail Transportation by Hydrogen vs. Electrification - Case Study for Ontario Canada, I: Propulsion and Storage”, International Journal of Hydrogen Energy, vol. 35, 6084 - 6096, 2010 [77] Marin, G., Naterer, G. F., Gabriel, K. S., "Rail Transportation by Hydrogen vs. Electrification - Case Study for Ontario Canada, II: Energy Supply and Distribution”, International Journal of Hydrogen Energy, vol. 35, pp. 6097 $-6107,2010$ 


\begin{tabular}{|c|c|c|c|c|}
\hline Step & Reaction & $\begin{array}{c}\text { Temp. } \\
\text { Range }\left({ }^{\circ} \mathrm{C}\right)\end{array}$ & \multicolumn{2}{c|}{$\begin{array}{c}\text { Feed } \\
\text { Output* }\end{array}$} \\
\hline 1 & $\begin{array}{c}2 \mathrm{CuCl}(\mathrm{aq})+2 \mathrm{HCl}(\mathrm{aq}) \rightarrow \\
\mathrm{H}_{2}(\mathrm{~g})+2 \mathrm{CuCl}_{2}(\mathrm{aq})\end{array}$ & $\begin{array}{c}<100 \\
(\text { electrolysis})\end{array}$ & $\begin{array}{c}\text { Feed: } \\
\text { Output: }\end{array}$ & $\begin{array}{c}\text { Aqueous } \mathrm{CuCl} \text { and } \mathrm{HCl}+\mathrm{V}+\mathrm{Q} \\
\mathrm{H}_{2}+\mathrm{CuCl}_{2}(\mathrm{aq})\end{array}$ \\
\hline 2 & $\mathrm{CuCl}_{2}(\mathrm{aq}) \rightarrow \mathrm{CuCl}_{2}(\mathrm{~s})$ & $<100$ & $\begin{array}{c}\text { Feed: } \\
\text { Output: }\end{array}$ & $\begin{array}{c}\text { Slurry containing } \mathrm{HCl}_{\text {and } \mathrm{CuCl}}+\mathrm{Q} \\
\text { Granular } \mathrm{CuCl}_{2}+\mathrm{H}_{2} \mathrm{O} / \mathrm{HCl} \text { vapours }\end{array}$ \\
\hline 3 & $\begin{array}{c}2 \mathrm{CuCl}_{2}(\mathrm{~s})+\mathrm{H}_{2} \mathrm{O}(\mathrm{g}) \rightarrow \\
\mathrm{Cu}_{2} \mathrm{OCl}_{2}(\mathrm{~s})+2 \mathrm{HCl}(\mathrm{g})\end{array}$ & 400 & $\begin{array}{c}\text { Feed: } \\
\text { Output: }\end{array}$ & $\begin{array}{c}\text { Powder/granular } \mathrm{CuCl}_{2}+\mathrm{H}_{2} \mathrm{O}(\mathrm{g})+\mathrm{Q} \\
\text { Powder/granular } \mathrm{Cu}_{2} \mathrm{OCl}_{2}+2 \mathrm{HCl}(\mathrm{g})\end{array}$ \\
\hline 4 & $\begin{array}{c}\mathrm{Cu}_{2} \mathrm{OCl}_{2}(\mathrm{~s}) \rightarrow 2 \mathrm{CuCl}(\mathrm{l})+1 / 2 \\
\mathrm{O} \mathrm{O}_{2}(\mathrm{~g})\end{array}$ & 500 & $\begin{array}{c}\text { Feed: } \\
\text { Output: }\end{array}$ & $\begin{array}{c}\text { Powder/granular } \mathrm{Cu}_{2} \mathrm{OCl}_{2}(\mathrm{~s})+\mathrm{Q} \\
\text { Molten } \mathrm{CuCl} \mathrm{salt}+\text { oxygen }\end{array}$ \\
\hline
\end{tabular}

Table 1: Steps and chemical reactions in the $\mathrm{Cu}-\mathrm{Cl}$ cycle

\begin{tabular}{|l|c|c|c|c|}
\hline \multicolumn{1}{|c|}{ Property } & $\begin{array}{c}\text { Conductivity } \\
(\mathrm{S} / \mathrm{cm})\end{array}$ & $\begin{array}{c}\text { Permeability } \\
\times 10^{-8}\left(\mathrm{~cm}^{2} / \mathrm{s}\right)\end{array}$ & $\begin{array}{c}\text { Selectivity } \\
\times 10^{6}\left(\mathrm{~S} \cdot \mathrm{s} / \mathrm{cm}^{2}\right)\end{array}$ & Cost $\left(\$ / \mathrm{m}^{2}\right)$ \\
\hline Nafion $^{\circledR} 117$ & 0.083 & 1.8 & 4.61 & 550 \\
\hline Nafion ${ }^{\circledR}$-based & $0.057-0.076$ & $0.15-1.92$ & $<39.5$ & $>550$ \\
\hline PPE & 0.050 & 1.6 & 3.1 & $10^{*}$ \\
\hline
\end{tabular}

Table 2: Properties of membranes in $\mathrm{CuCl} / \mathrm{HCl}$ electrolyzer (* does not include coating costs)

\begin{tabular}{|c|c|c|c|c|c|c|}
\hline $\begin{array}{c}\text { Temperatur } \\
\text { e change } \\
\left({ }^{\circ} \mathrm{C}\right)\end{array}$ & $\begin{array}{c}\text { Cooling } \\
\text { time } \\
(\mathrm{min})\end{array}$ & Cooling method & $\begin{array}{c}\text { Initial total } \\
\text { water }(\mathrm{g})\end{array}$ & $\begin{array}{c}\text { Measured } \\
\text { anhydrous } \\
\mathrm{CuCl}_{2}(\mathrm{~g})\end{array}$ & $\begin{array}{c}\text { Ratio } \\
\text { (measured) }\end{array}$ & $\begin{array}{c}\text { Ratio } \\
\text { (theory) }\end{array}$ \\
\hline $80 \rightarrow 30$ & 37 & $\begin{array}{c}\text { Forced convection } \\
\text { with water }\end{array}$ & 312.94 & 93.5 & 0.299 & 0.189 \\
\hline $80 \rightarrow 20$ & 102 & $\begin{array}{c}\text { Free convection, } \\
\text { thermal bath }\end{array}$ & 313.08 & 106.79 & 0.341 & 0.238 \\
\hline $80 \rightarrow 21$ & 72.5 & $\begin{array}{c}\text { Free convection } \\
\text { with room air }\end{array}$ & 312.83 & 109.59 & 0.35 & 0.238 \\
\hline $80 \rightarrow 5$ & 87 & $\begin{array}{c}\text { Forced convection } \\
\text { in ice water }\end{array}$ & 313.08 & 115.66 & 0.369 & 0.27 \\
\hline
\end{tabular}

Table 3: Comparison of experimental and predicted heat recovery by crystallization of $\mathrm{CuCl}_{2}$ 


\section{$\underline{\text { List of Figure Captions }}$}

- Figure 1: Schematic of the copper-chlorine $(\mathrm{Cu}-\mathrm{Cl})$ cycle

- Figure 2: Schematic of $\mathrm{CuCl} / \mathrm{HCl}$ electrolysis process

- Figure 3: (a) Variation of cell voltage and catholyte copper species concentration with time and (b) effects of temperature on cell voltage for the constant current densities indicated in the legend

- Figure 4: Current density vs. (a) voltage and (b) hydrogen production rate at two flow rates

- Figure 5: Droplet drying processes

- Figure 6: Blowhole formation in spray drying experiment

- Figure 7: Schematic of spray drying apparatus

- Figure 8: Particle moisture content (note: adjoining correlations for $150 \mathrm{C}$ and $130 \mathrm{C}$ refer to 5 and 10 minute sample removal frequency)

- $\quad$ Figure 9: Experimental apparatus for crystallization experiments

- Figure 10: Stages of crystallization in concentrating $\mathrm{CuCl}_{2}$

- Figure 11: Schematic of hydrolysis experimental apparatus

- Figure 12: Measurements of (a) incoming excess steam requirement and (b) exiting $\mathrm{HCl}$ fraction

- Figure 13: XRD measurements and evidence of $\mathrm{CuCl}_{2}, \mathrm{CuCl}$, and $\mathrm{Cu}_{2} \mathrm{OCl}_{2}$ products

- Figure 14: Experimental apparatus for $\mathrm{CuO}^{*} \mathrm{CuCl}_{2}$ decomposition

- Figure 15: Schematic of physical processes during particle decomposition

- Figure 16: Predicted and measured rates of solid conversion of $\mathrm{CuCl}_{2}$ to $\mathrm{Cu}_{2} \mathrm{OCl}_{2}$

- Figure 17: Schematic of bubble diffusion experiments

- Figure 18: Sherwood number correlation for mass transfer at bubble interface

- Figure 19: (a) Thermal imaging and (b) solidified particles after quenching of molten $\mathrm{CuCl} 2$ in water

- Figure 20: X-ray diffraction of solidified CuCl droplets immersed in air and quenched in water

- Figure 21: Integration of electrolysis and hydrolysis steps

- Figure 22: Azeotropic $\mathrm{HCl}$ concentration for $\mathrm{HCl}-\mathrm{H}_{2} \mathrm{O}$ system at varying temperatures

- Figure 23: SCW and SHS temperature and heat transfer coefficients in intermediate heat exchanger

- Figure 24: Half-cell EIS measurements for CCE anodes prepared from different organosilane precursors shown as (a) Nyquist plots and (b) capacitance plots (note: measurements made in a half-cell with $1.5 \mathrm{M} \mathrm{HCl}$ at $25^{\circ} \mathrm{C}$ )

- Figure 25: (a) Experimental apparatus for full cell electrolysis cell testing and (b) full cell polarization curve for the electrolysis of $\mathrm{CuCl} / \mathrm{HCl}$ solution using PAPS-based CCE anodes with different PAPS loadings (note: measurements made at $25^{\circ} \mathrm{C}$ with $0.2 \mathrm{M} \mathrm{CuCl}$ in $2 \mathrm{M} \mathrm{HCl}$ flowing at the anode and pure water flowing at the cathode). (c) Full cell capacitance plots obtained for PAPSbased CCE anodes with different PAPS loadings. Note: measurements made at $25^{\circ} \mathrm{C}$ with $2 \mathrm{M} \mathrm{HCl}$ flowing at the anode (working electrode) and $\mathrm{H}_{2}$ gas supplied to the cathode (counter and reference electrodes)

- Figure 26: Schematic of immersion cell apparatus for material corrosion testing in molten $\mathrm{CuCl}$

- Figure 27: SEM and EDX results for (a) Inconel 625 and (b) AL6XN Stainless Steel 


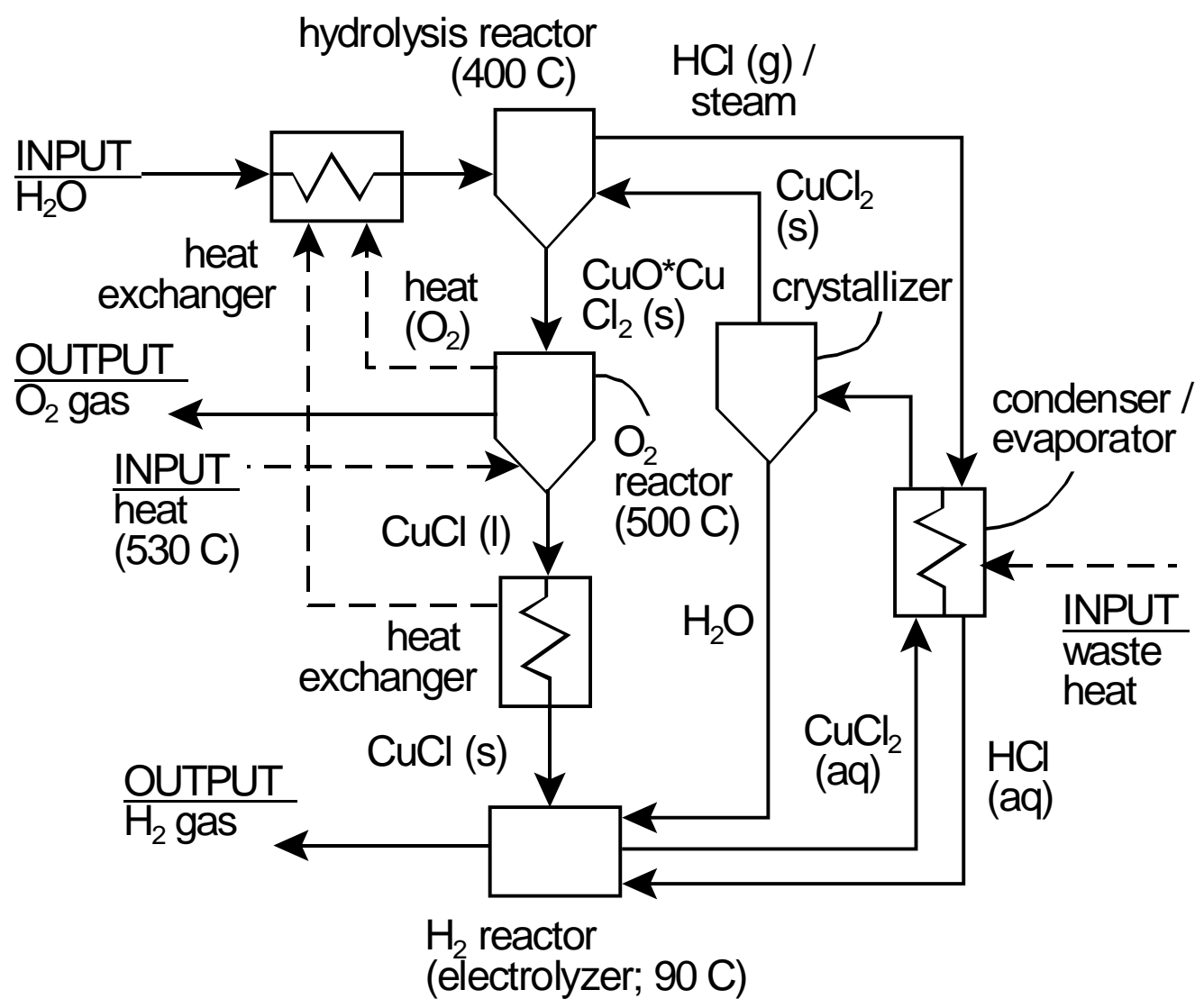

Figure 1: Schematic of the copper-chlorine (Cu-Cl) cycle 


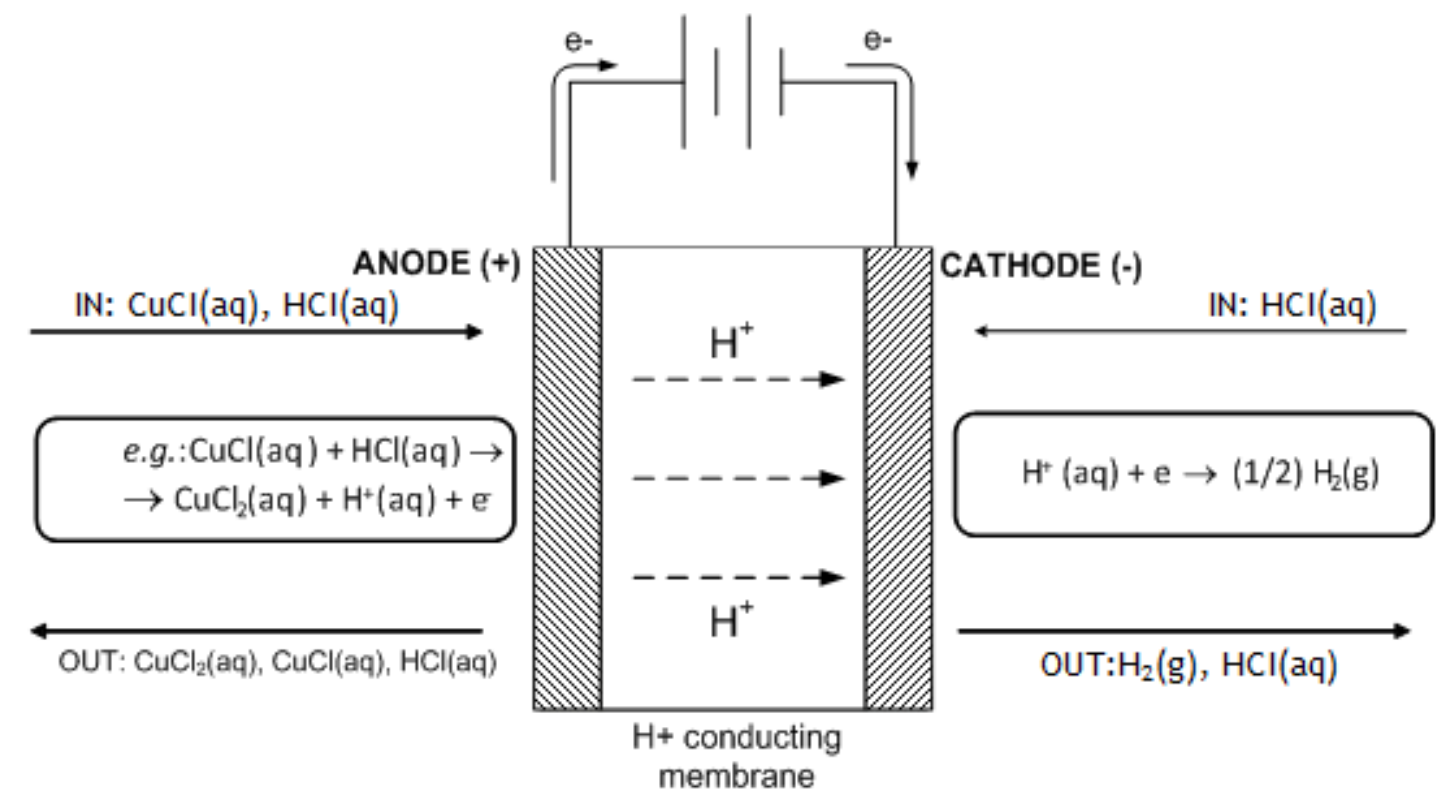

Figure 2: Schematic of $\mathrm{CuCl} / \mathrm{HCl}$ electrolysis process

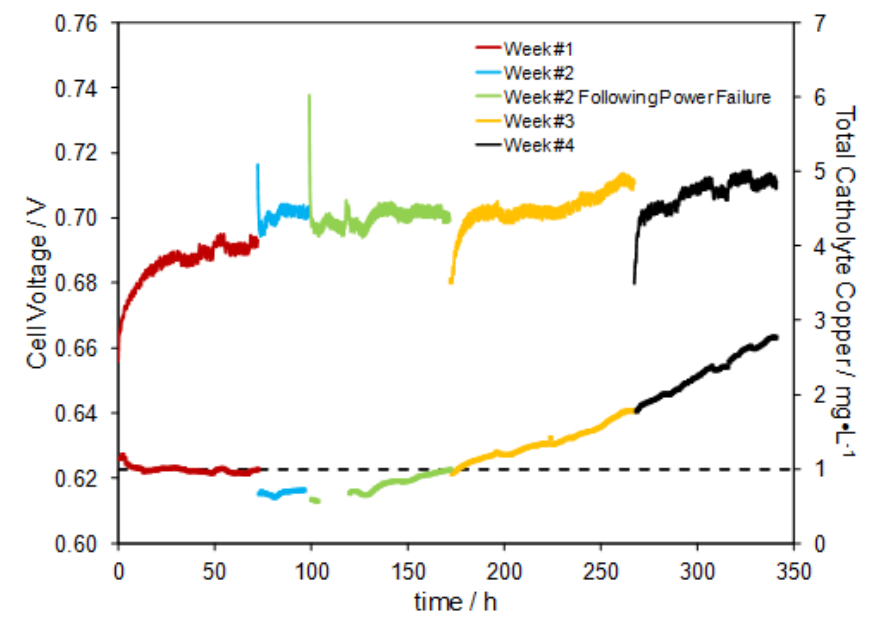

(a)

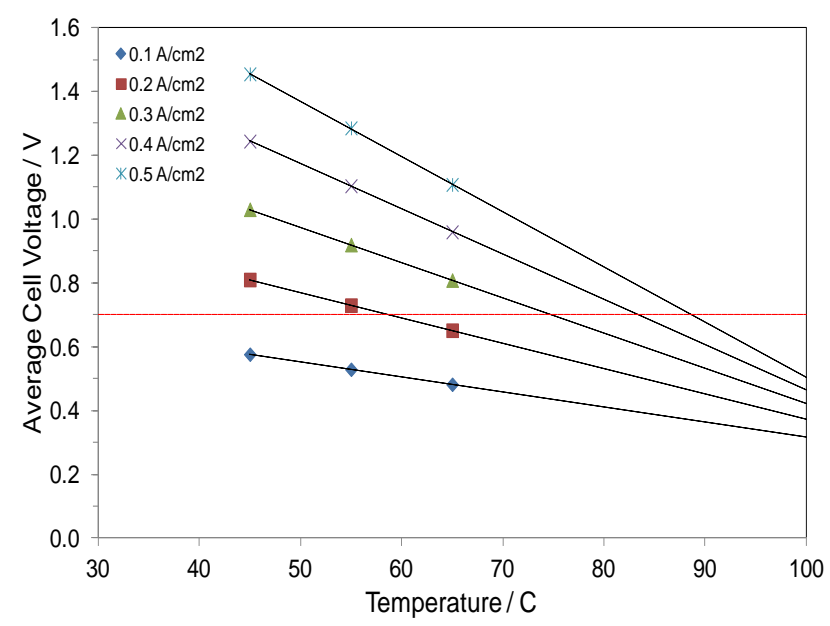

(b)

Figure 3: (a) Variation of cell voltage and catholyte copper species concentration with time and (b) effects of temperature on cell voltage for the constant current densities indicated in the legend 


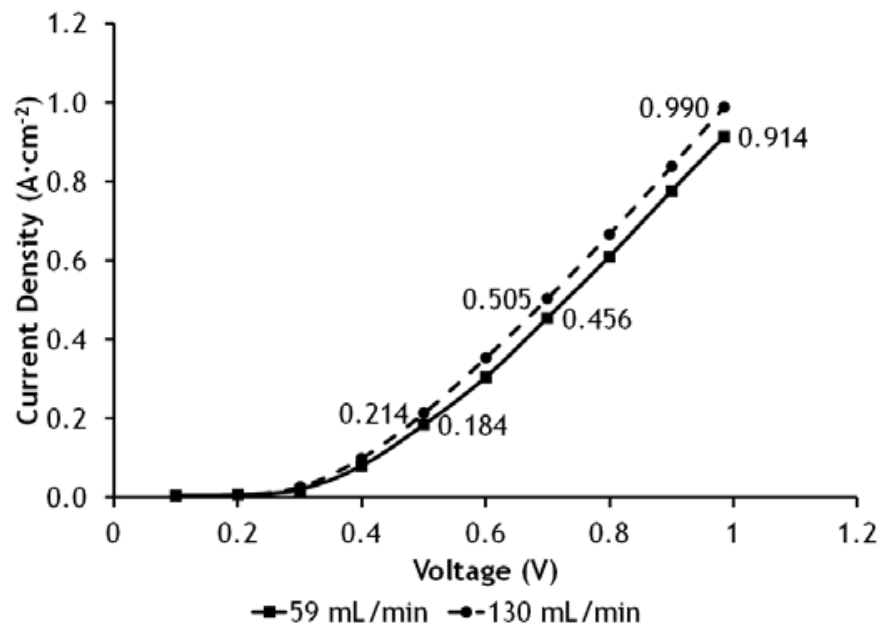

(a)

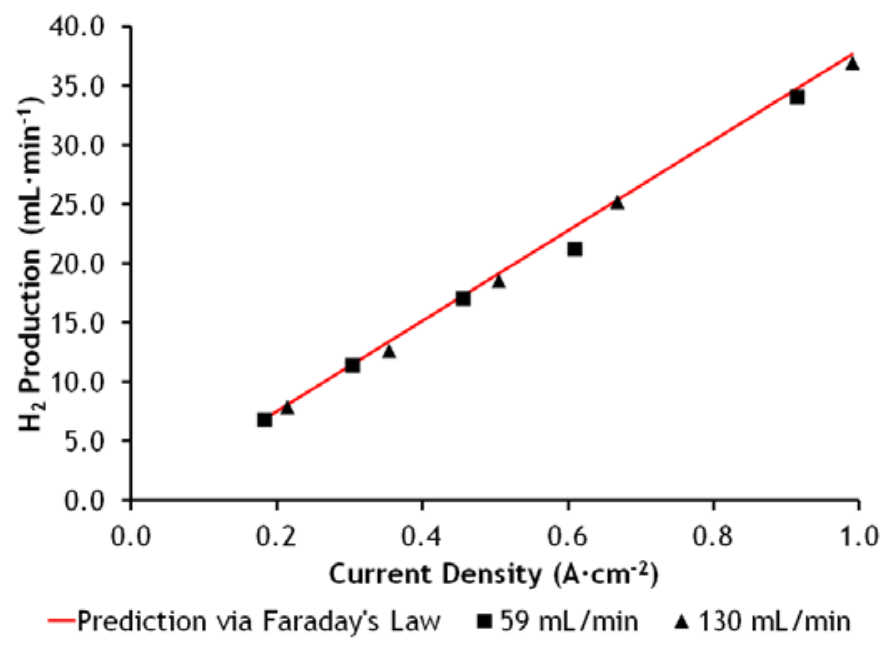

(b)

Figure 4: Current density vs. (a) voltage and (b) hydrogen production rate at two flow rates

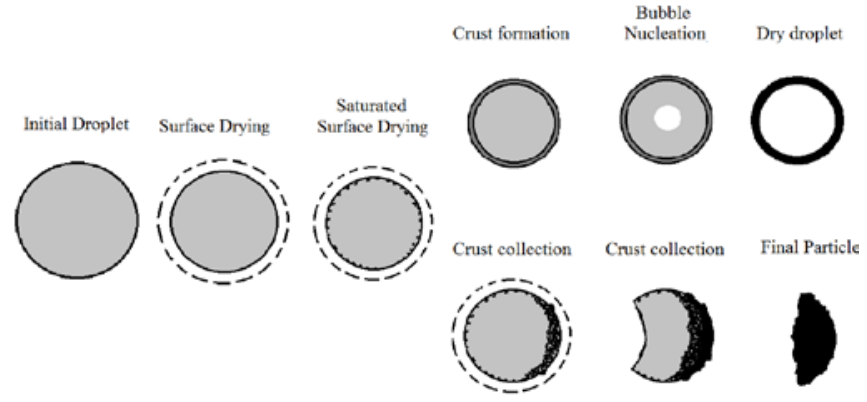

Figure 5: Droplet drying processes

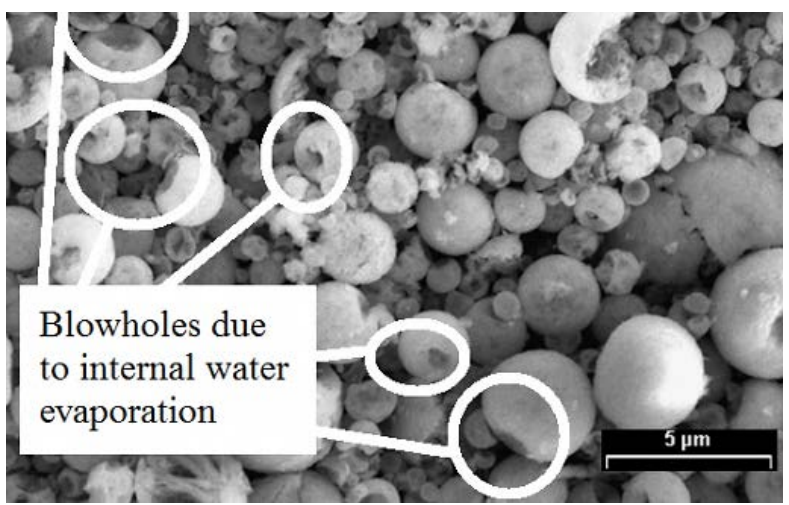

Figure 6: Blowhole formation in spray drying experiment 


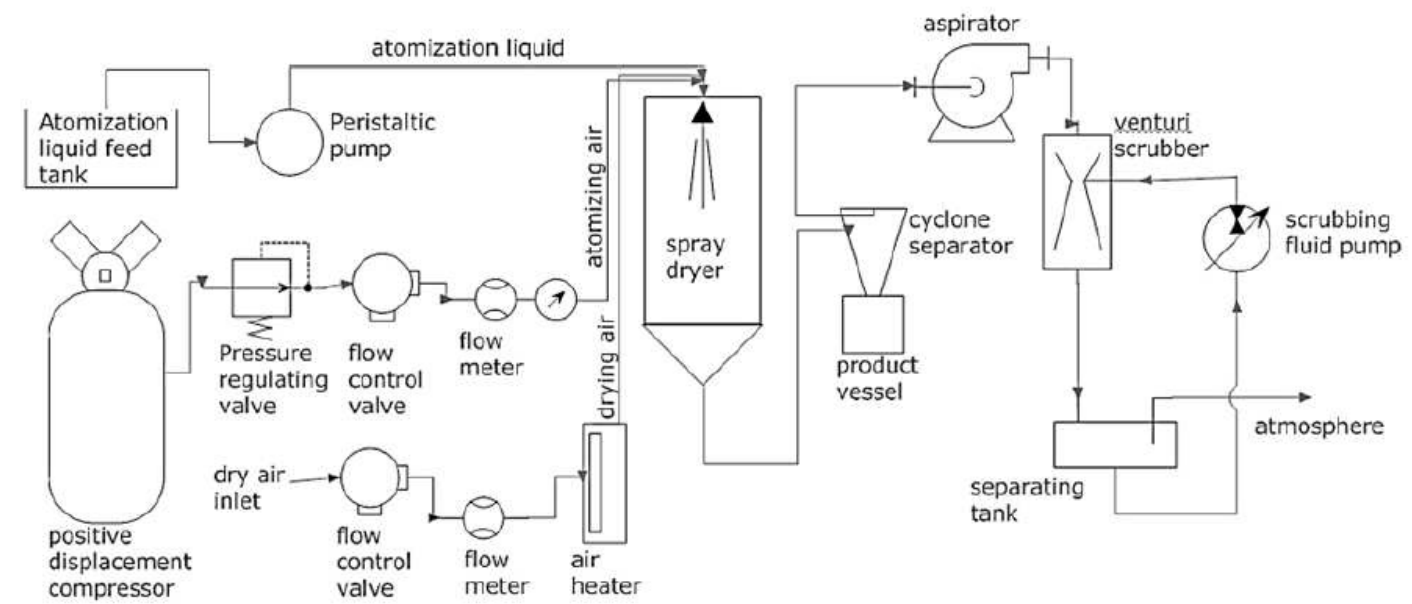

Figure 7: Schematic of spray drying apparatus

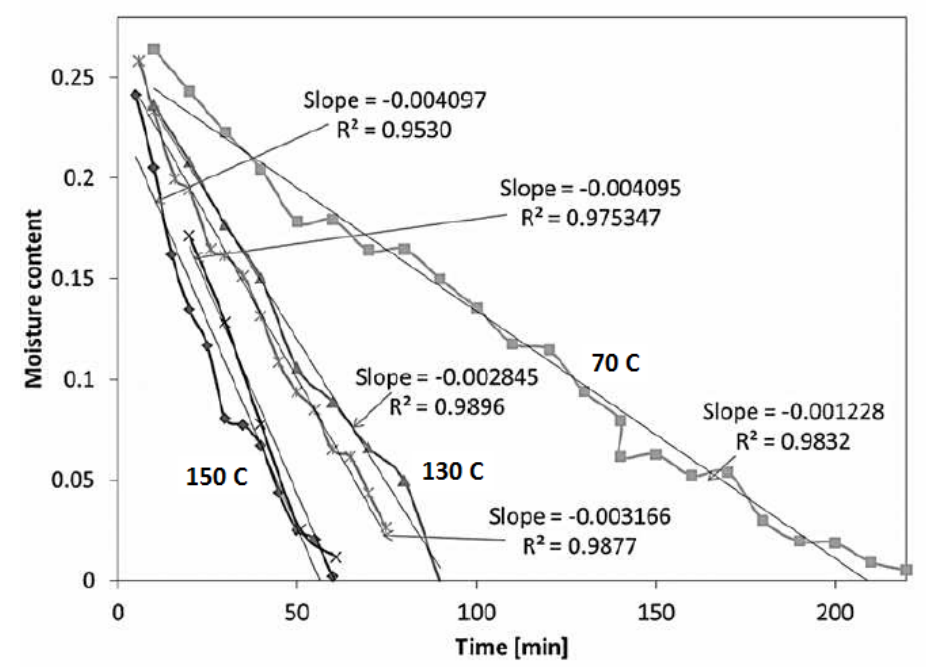

Figure 8: Particle moisture content (note: adjoining correlations for $150 \mathrm{C}$ and $130 \mathrm{C}$ refer to 5 and 10 minute sample removal frequency) 


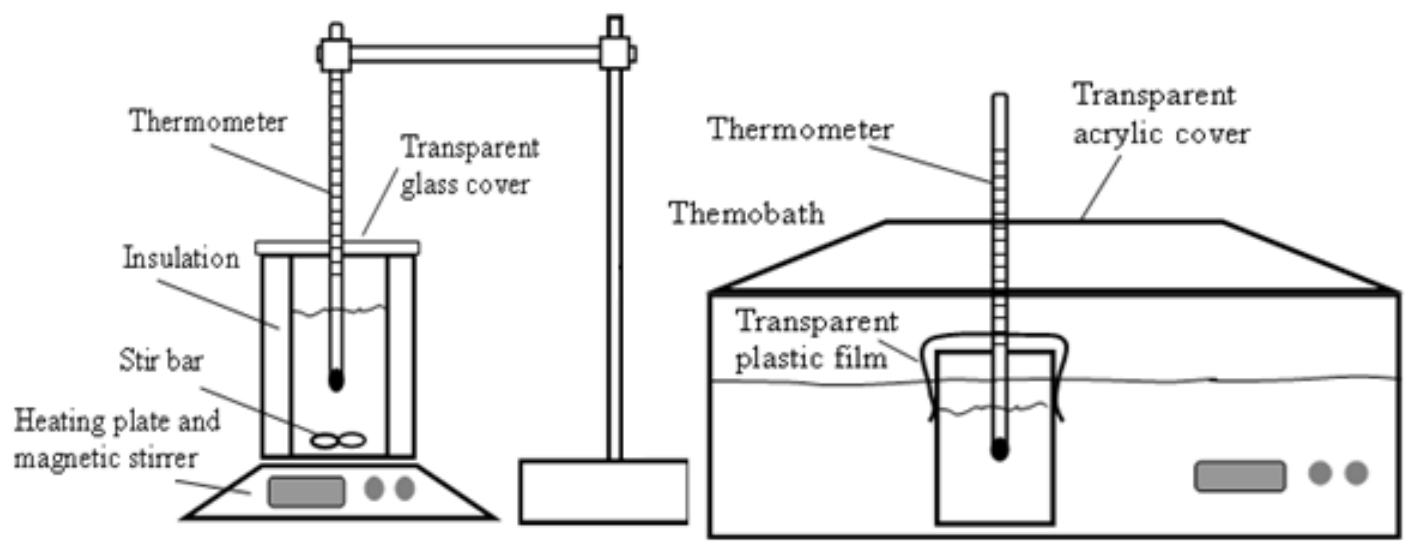

Figure 9: Experimental apparatus for crystallization experiments 


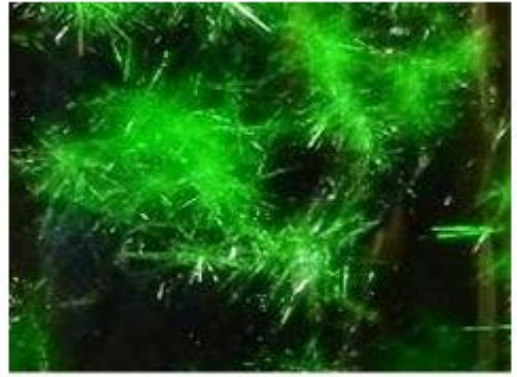

(a) Crystal starts to appear

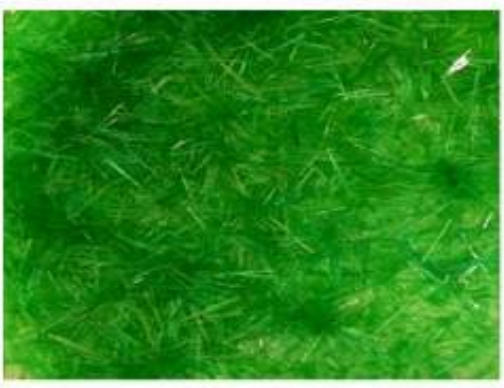

(c) After clear solution is removed

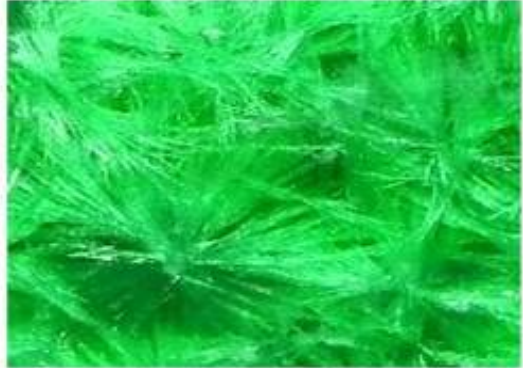

(b) Crystal growth becomes denser

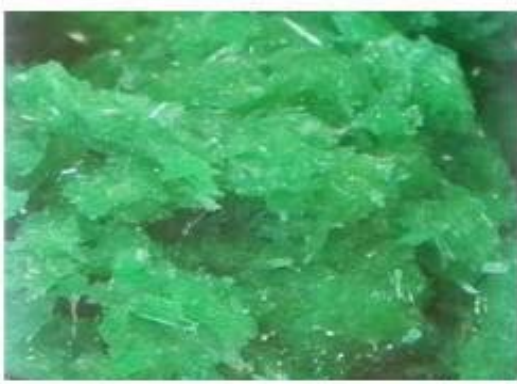

(d) After crystals are squeezed

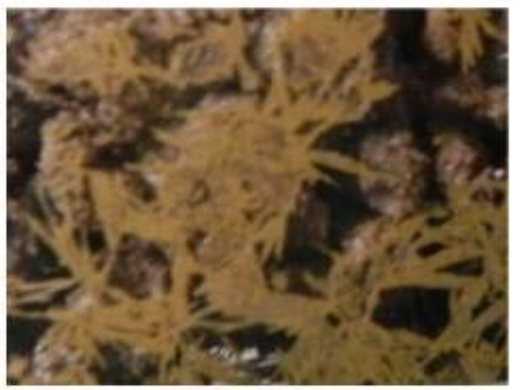

(e) After hydrated water is removed

Figure 10: Stages of crystallization in concentrating $\mathrm{CuCl}_{2}$ 


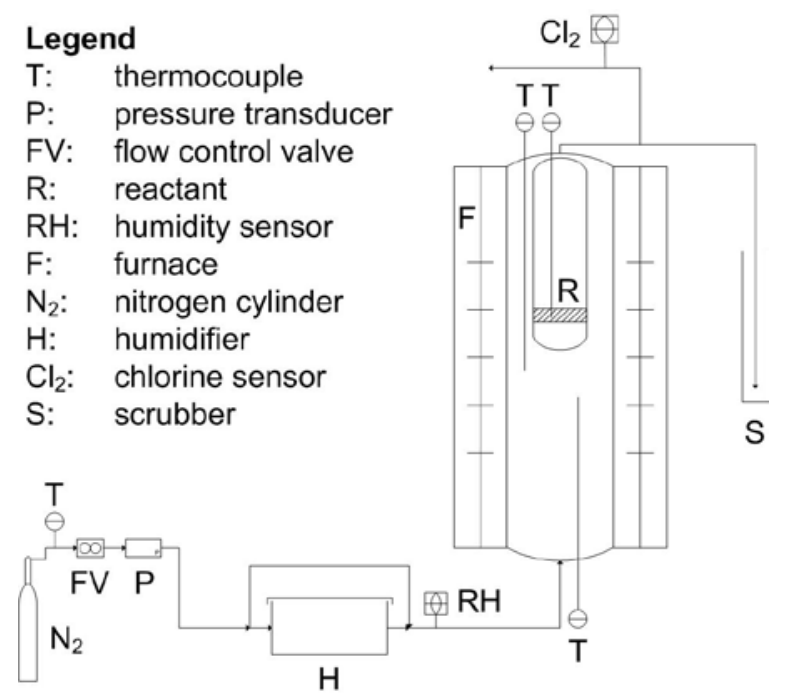

Figure 11: Schematic of hydrolysis experimental apparatus
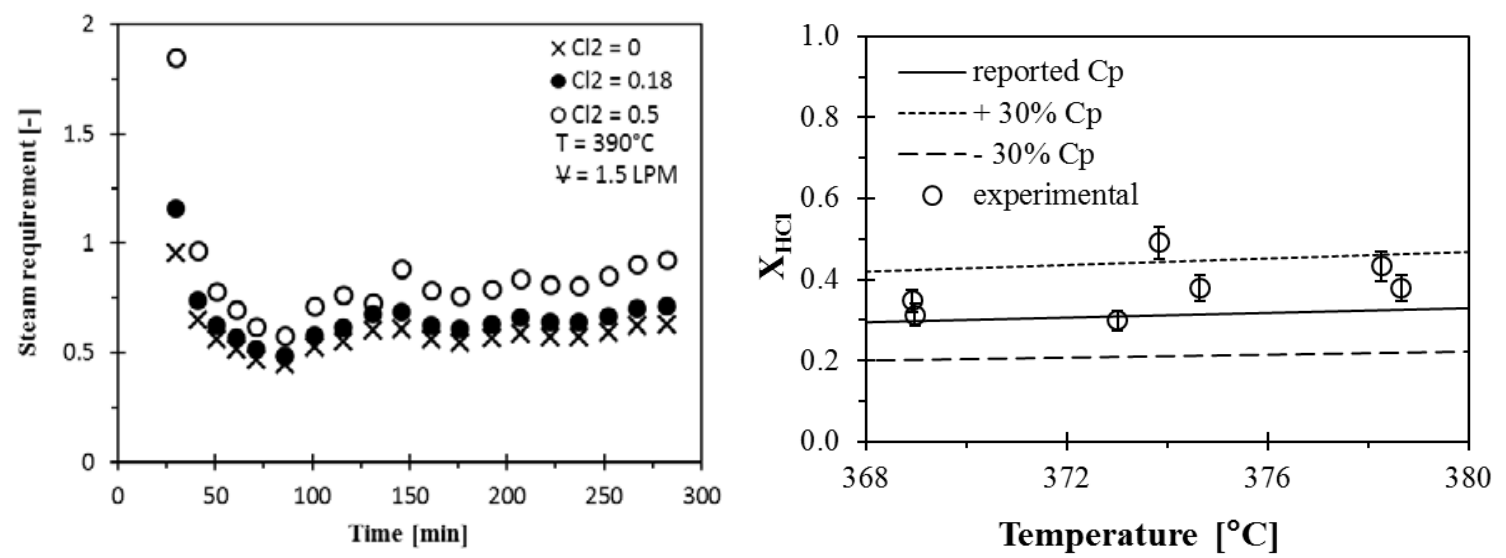

Figure 12: Measurements of (a) incoming excess steam requirement and (b) exiting $\mathrm{HCl}$ fraction

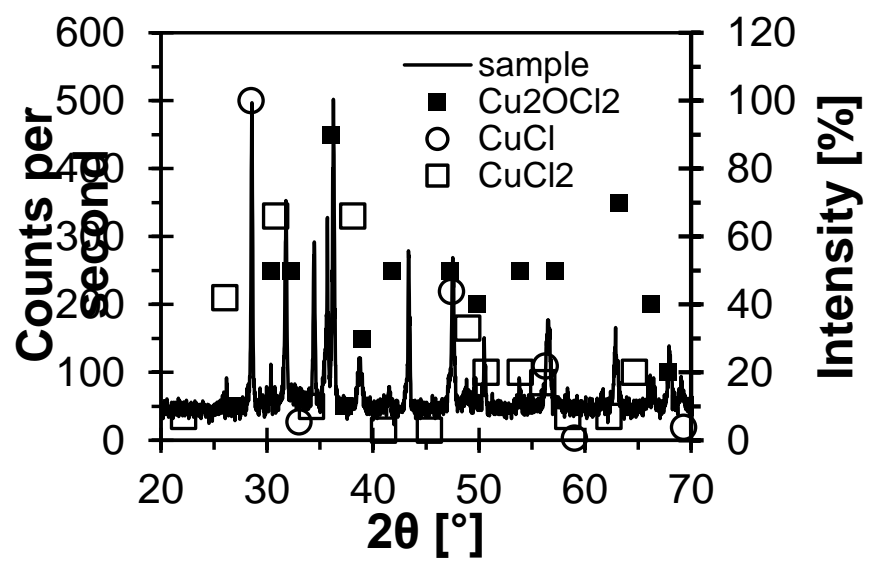


Figure 13: XRD measurements and evidence of $\mathrm{CuCl}_{2}, \mathrm{CuCl}$, and $\mathrm{Cu}_{2} \mathrm{OCl}_{2}$ products

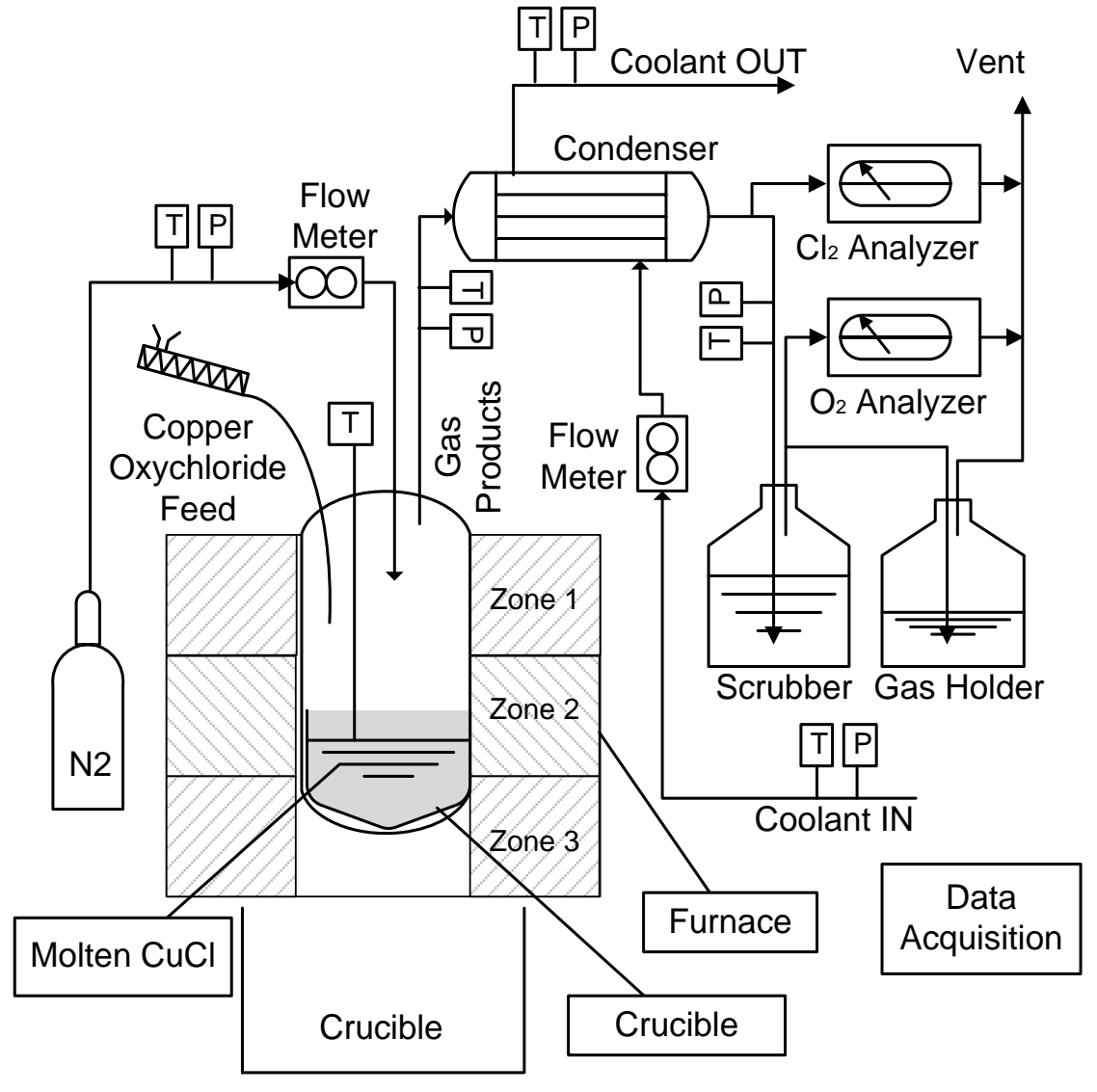

Fig. 14: Experimental apparatus for $\mathrm{CuO}^{*} \mathrm{CuCl}_{2}$ decomposition 


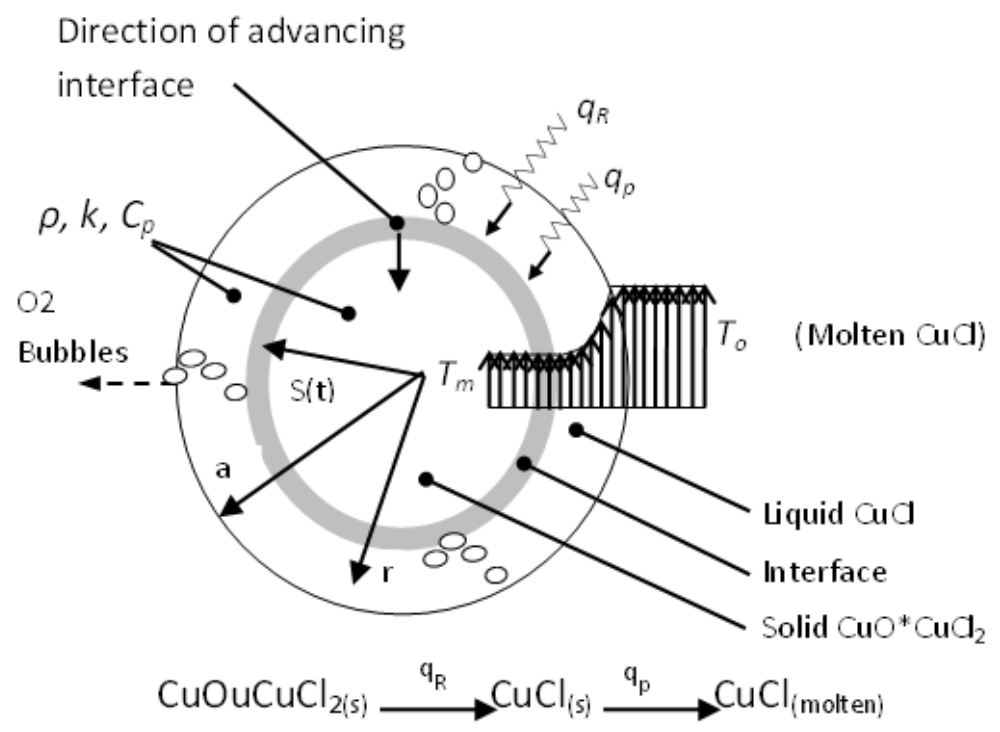

Fig. 15: Schematic of physical processes during particle decomposition

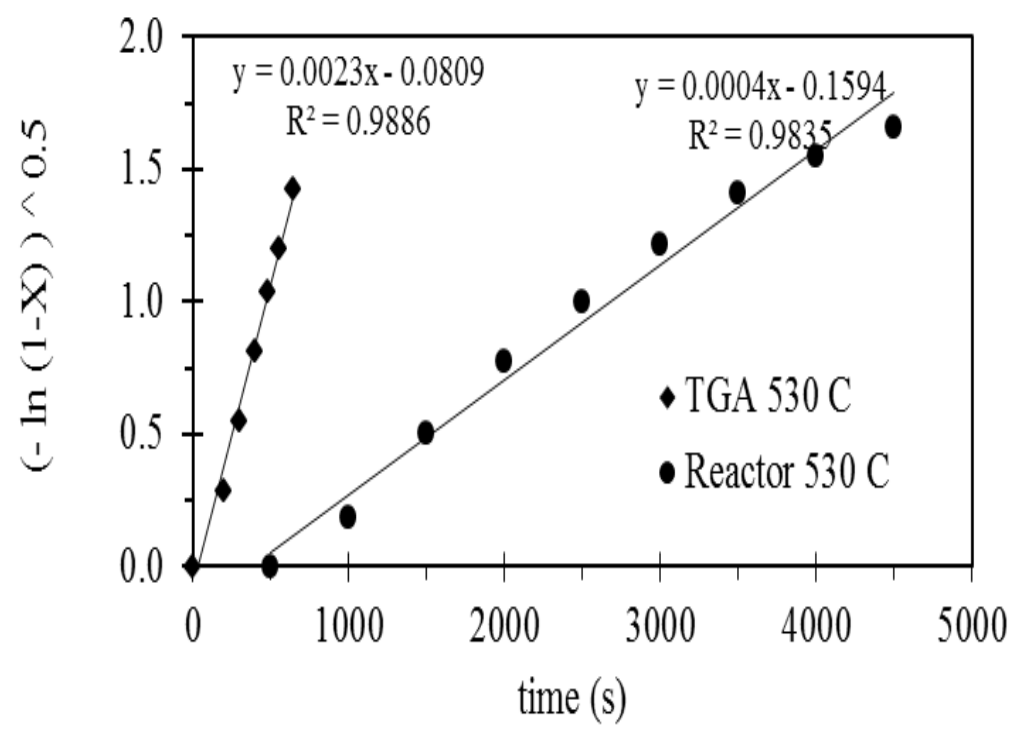

Figure 16: Predicted and measured rates of solid conversion of $\mathrm{CuCl}_{2}$ to $\mathrm{Cu}_{2} \mathrm{OCl}_{2}$ 


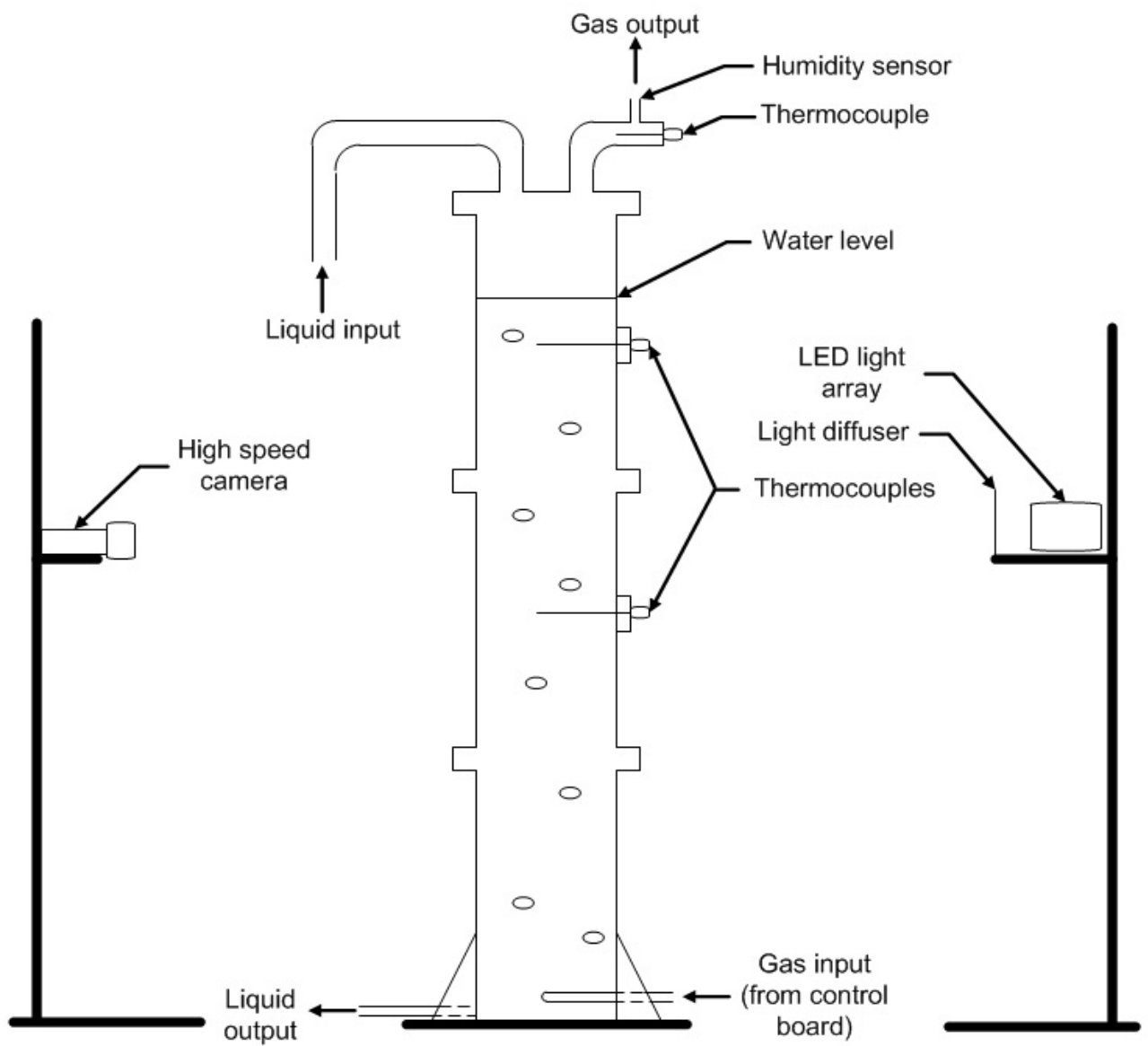

Figure 17: Schematic of bubble diffusion experiments

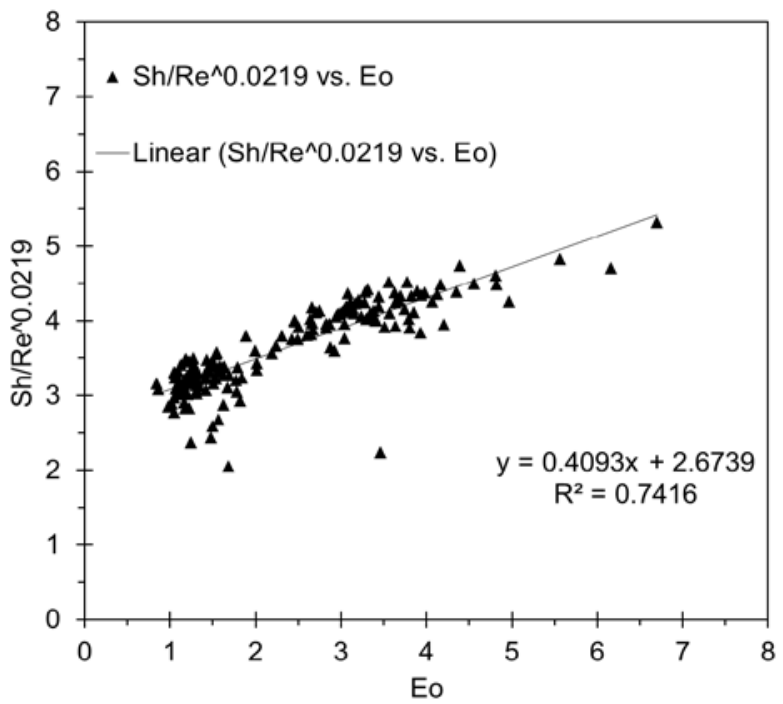


Fig. 18: Sherwood number correlation for mass transfer at bubble interface

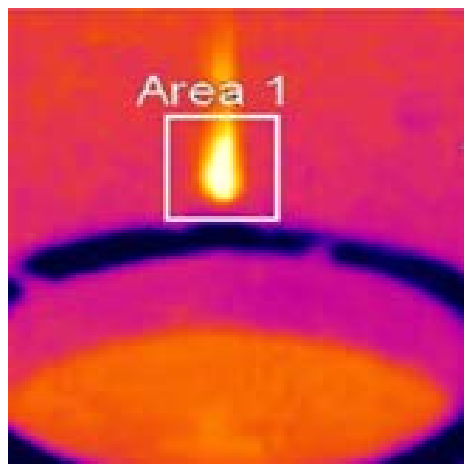

(a)

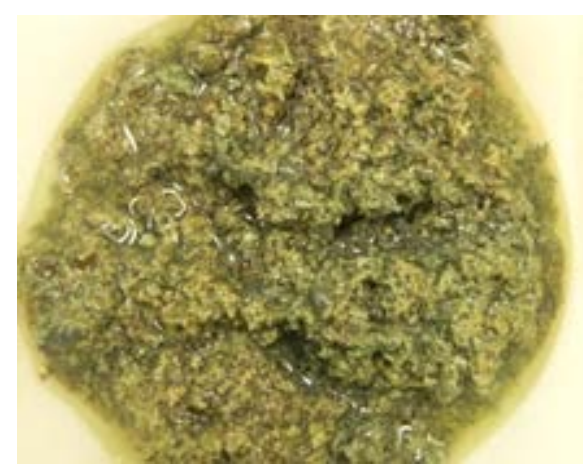

(b)

Figure 19: (a) Thermal imaging and (b) solidified particles after quenching of molten $\mathrm{CuCl}_{2}$ in water

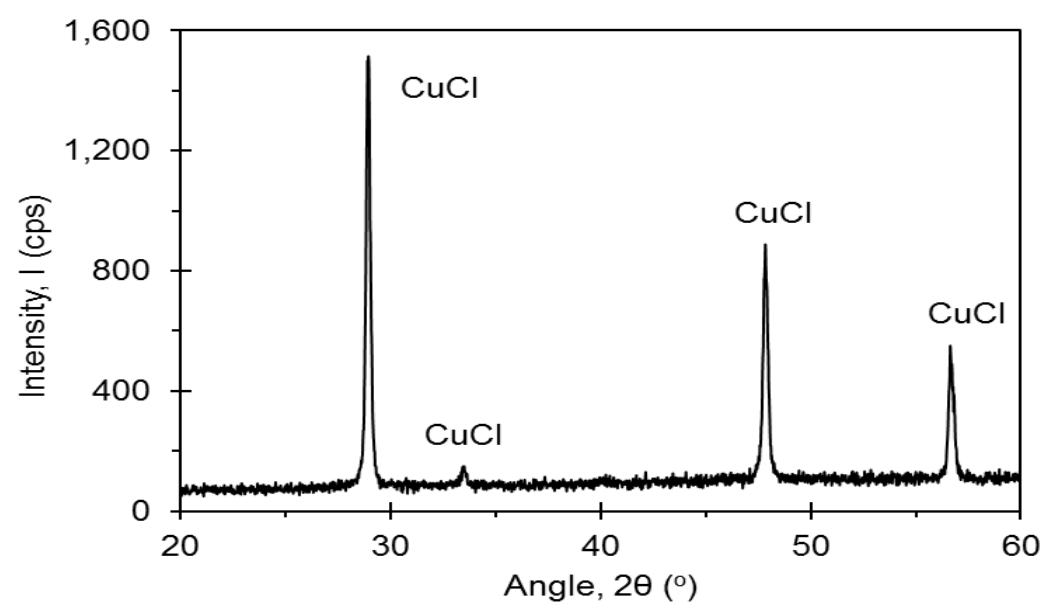

Figure 20: X-ray diffraction of solidified $\mathrm{CuCl}$ droplets immersed in air and quenched in water 


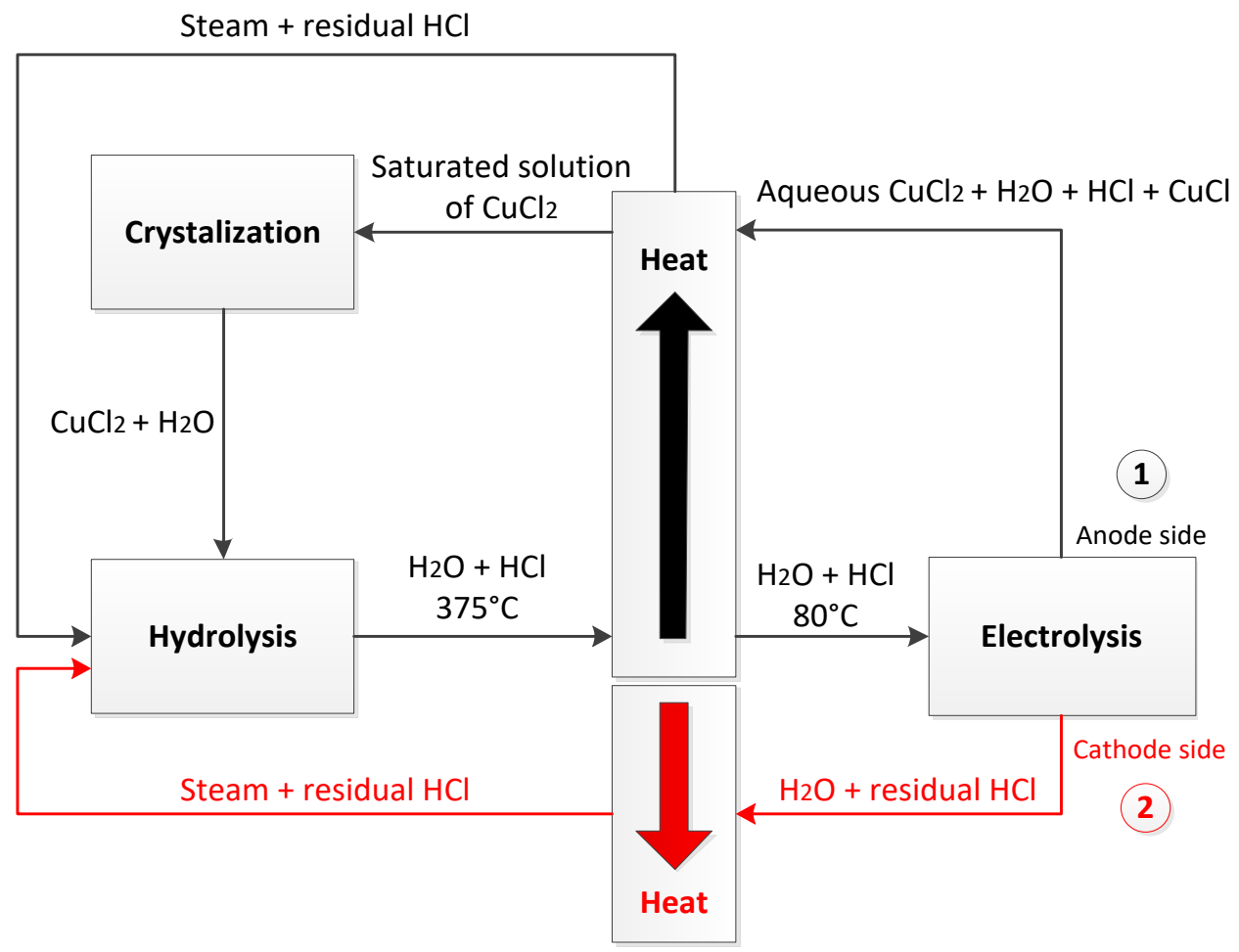

Figure 21: Integration of electrolysis and hydrolysis steps 


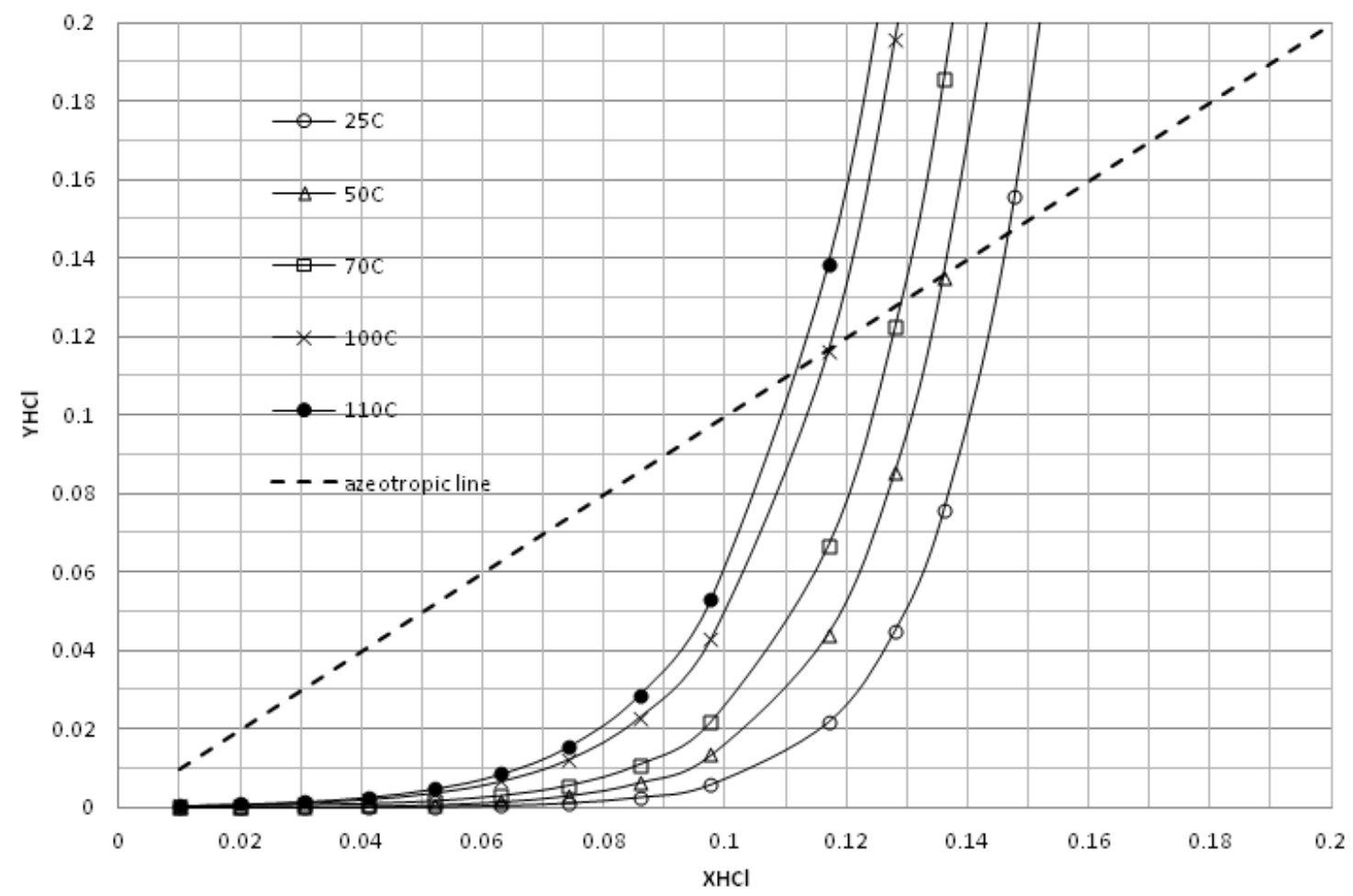

Figure 22: Azeotropic $\mathrm{HCl}$ concentration for $\mathrm{HCl}-\mathrm{H}_{2} \mathrm{O}$ system at varying temperatures 


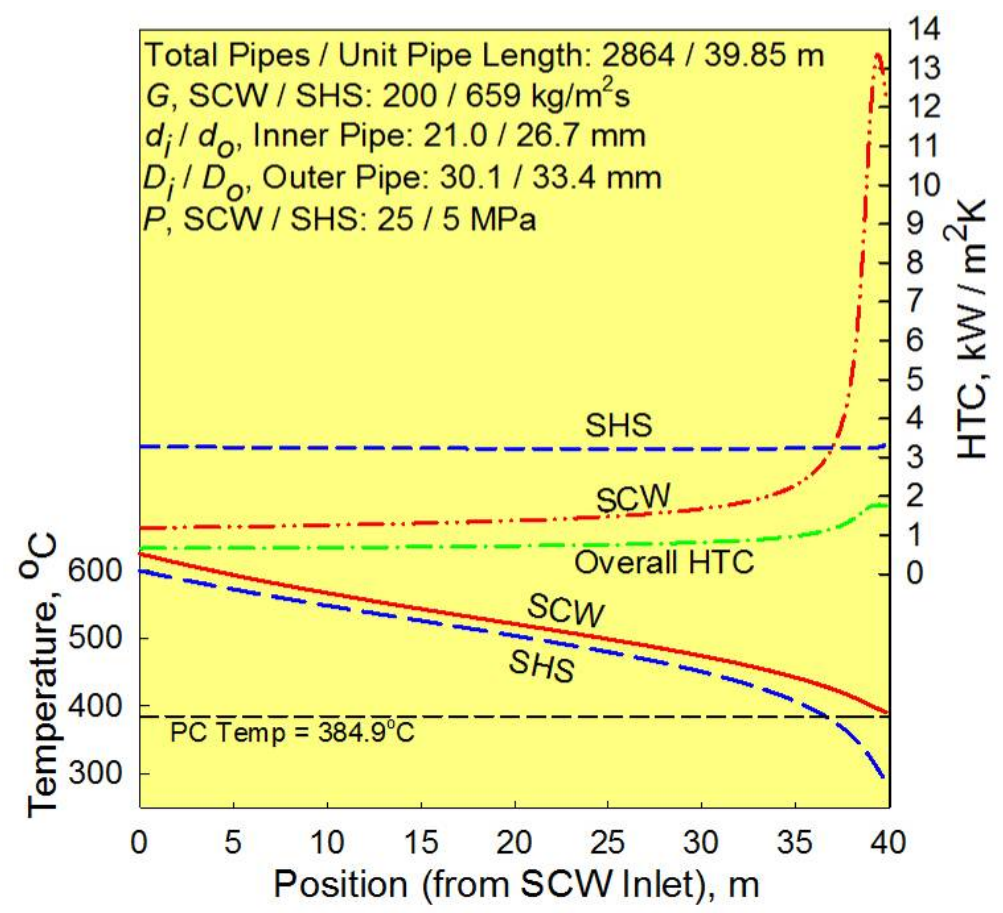

Figure 23: SCW and SHS temperature and heat transfer coefficients in intermediate heat exchanger

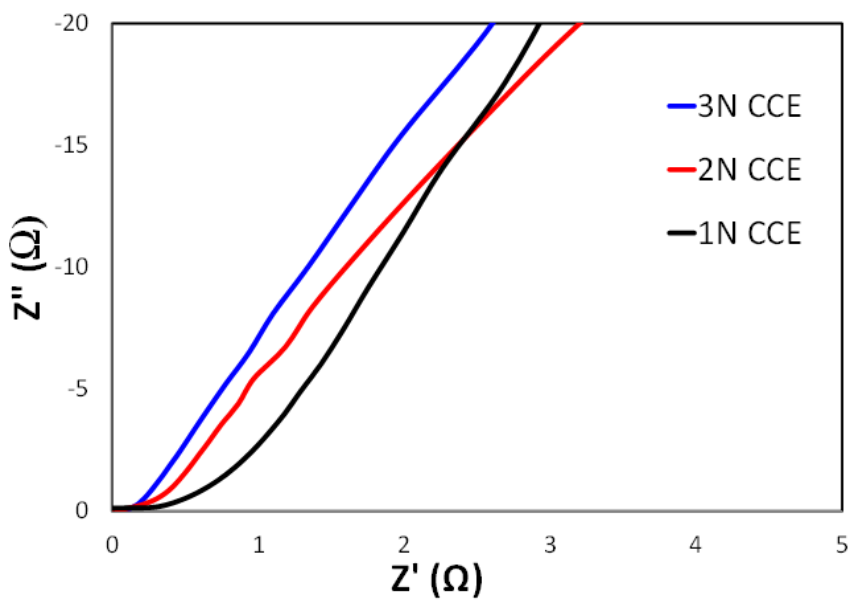

(a)

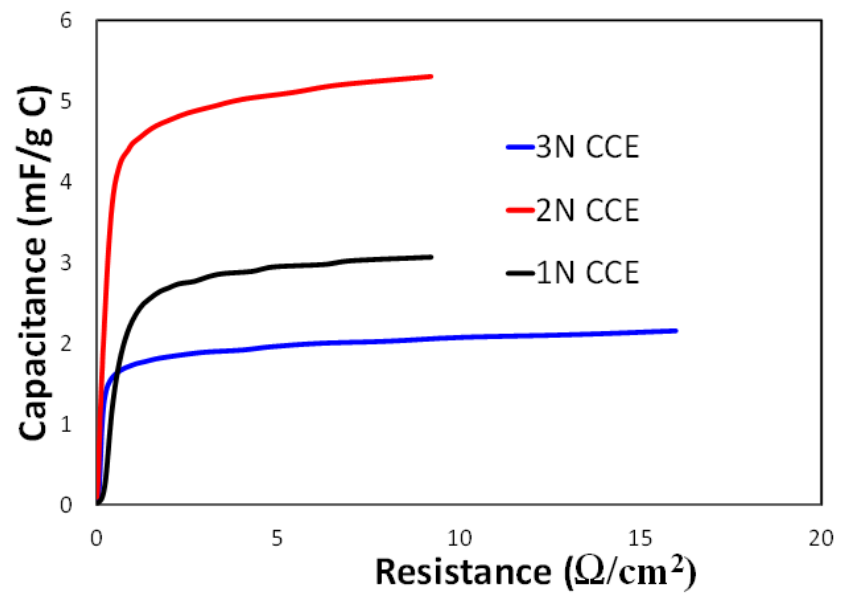

(b)

Figure 24: Half-cell EIS measurements for CCE anodes prepared from different organosilane precursors shown as (a) Nyquist plots and (b) capacitance plots (note: measurements made in a half-cell with $1.5 \mathrm{M} \mathrm{HCl}$ at $25^{\circ} \mathrm{C}$ ) 


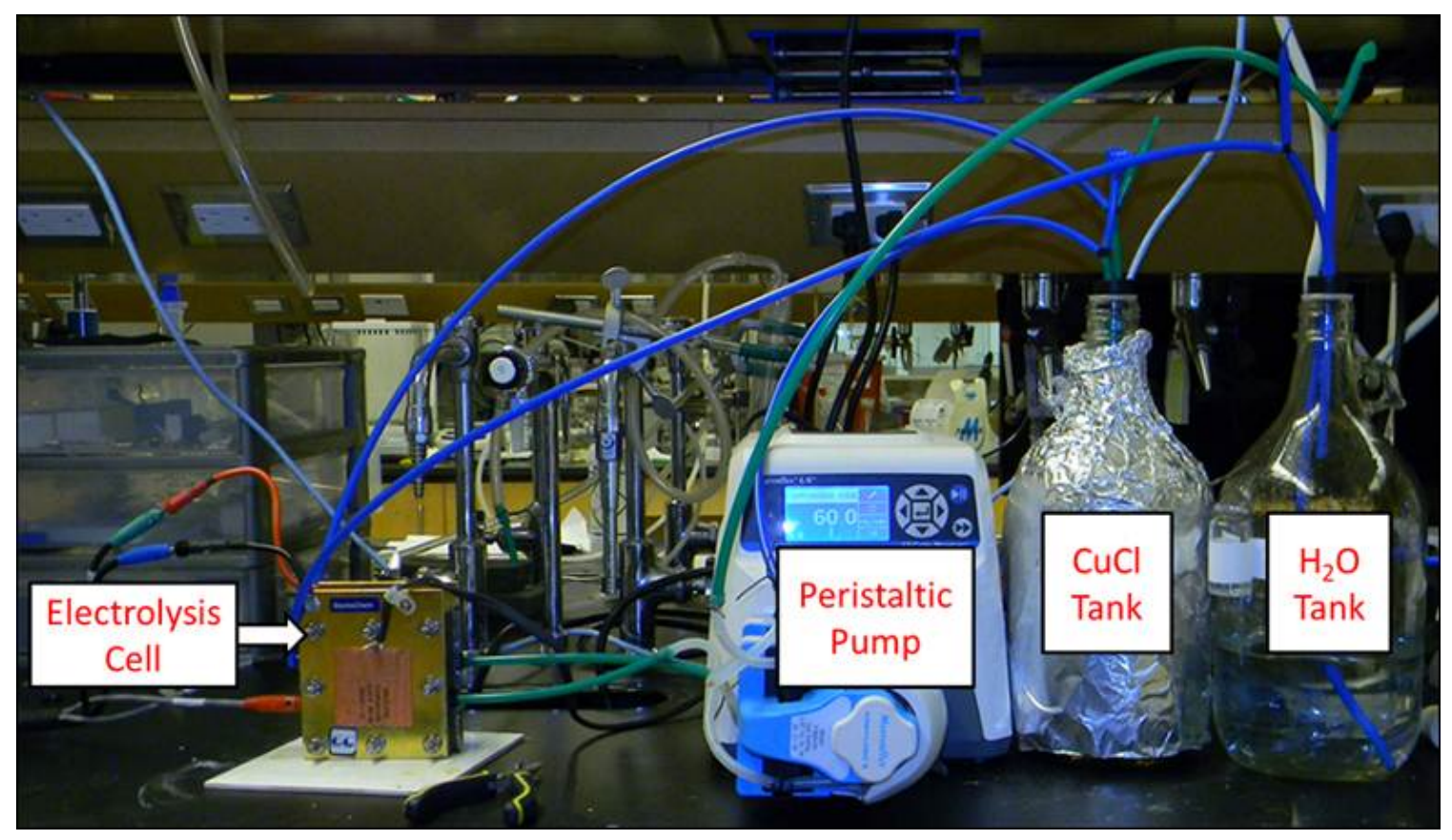

(a)

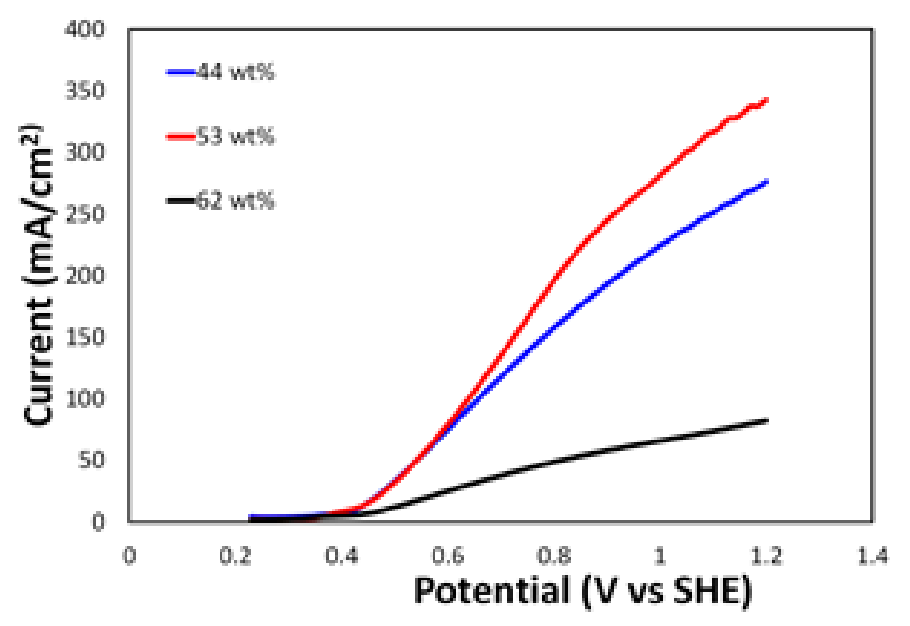

(b)

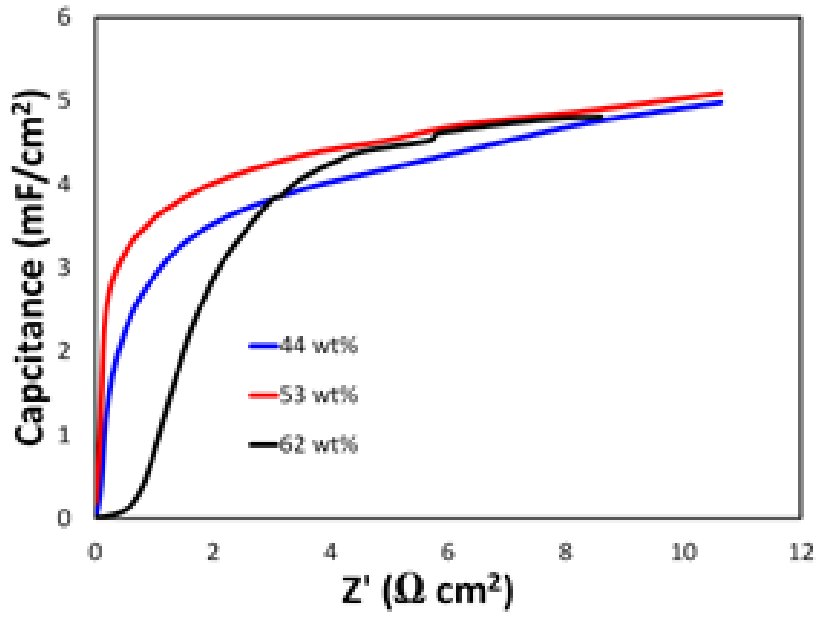

(c)

Figure 25: (a) Experimental apparatus for full cell electrolysis cell testing and (b) full cell polarization curve for the electrolysis of $\mathrm{CuCl} / \mathrm{HCl}$ solution using PAPS-based CCE anodes with different PAPS loadings (note: measurements made at $25{ }^{\circ} \mathrm{C}$ with $0.2 \mathrm{M} \mathrm{CuCl}$ in $2 \mathrm{M} \mathrm{HCl}$ flowing at the anode and pure water flowing at the cathode). (c) Full cell capacitance plots obtained for PAPS-based CCE anodes with different PAPS loadings. Note: measurements made at 
$25{ }^{\circ} \mathrm{C}$ with $2 \mathrm{M} \mathrm{HCl}$ flowing at the anode (working electrode) and $\mathrm{H}_{2}$ gas supplied to the cathode (counter and reference electrodes)

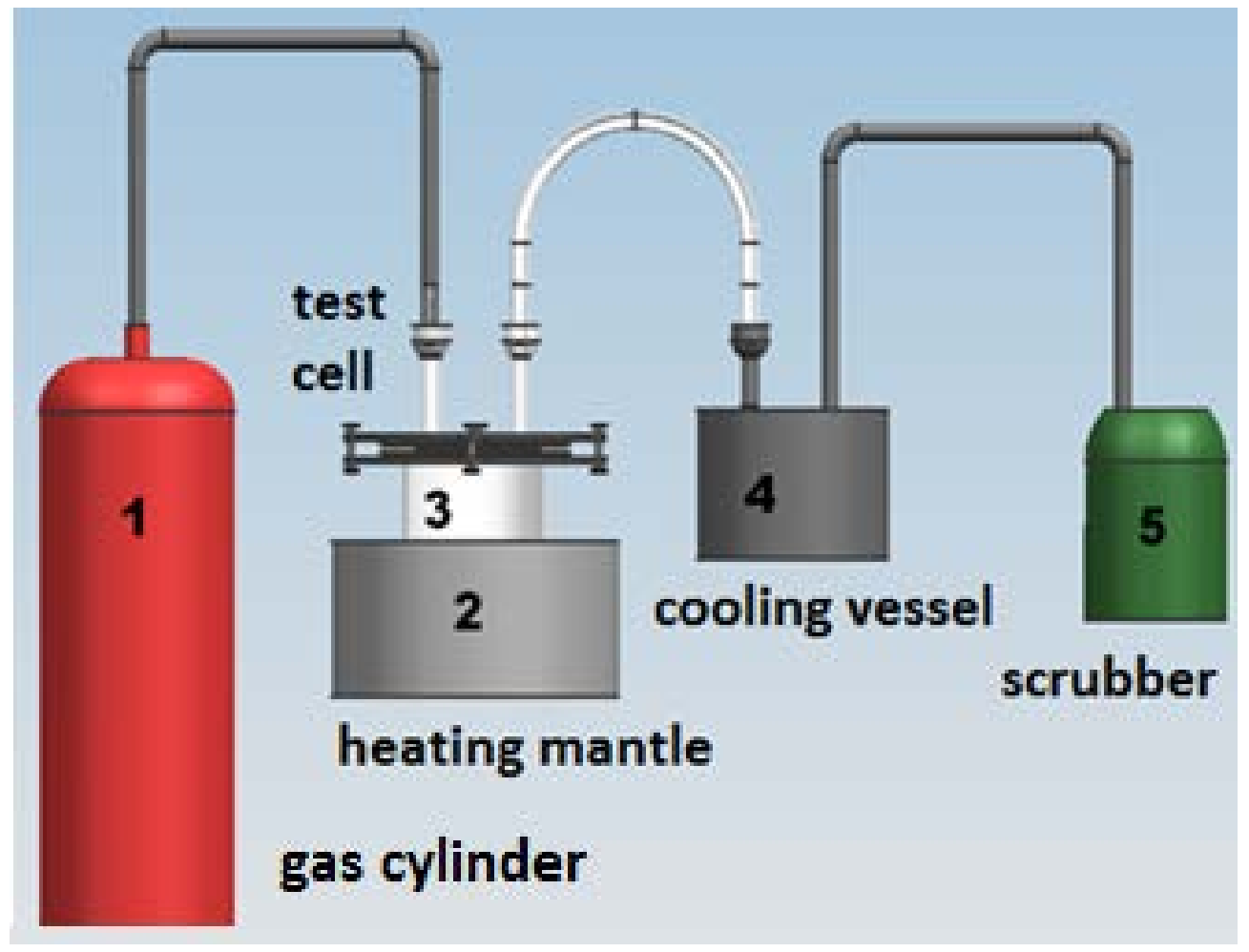

Figure 26: Schematic of immersion cell apparatus for material corrosion testing in molten $\mathrm{CuCl}$ 


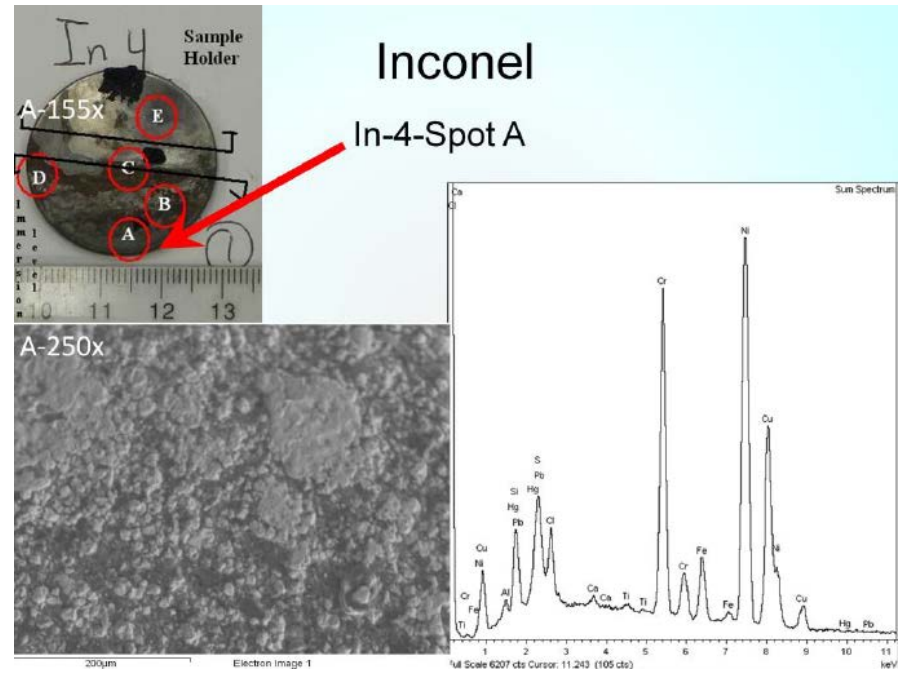

(a)

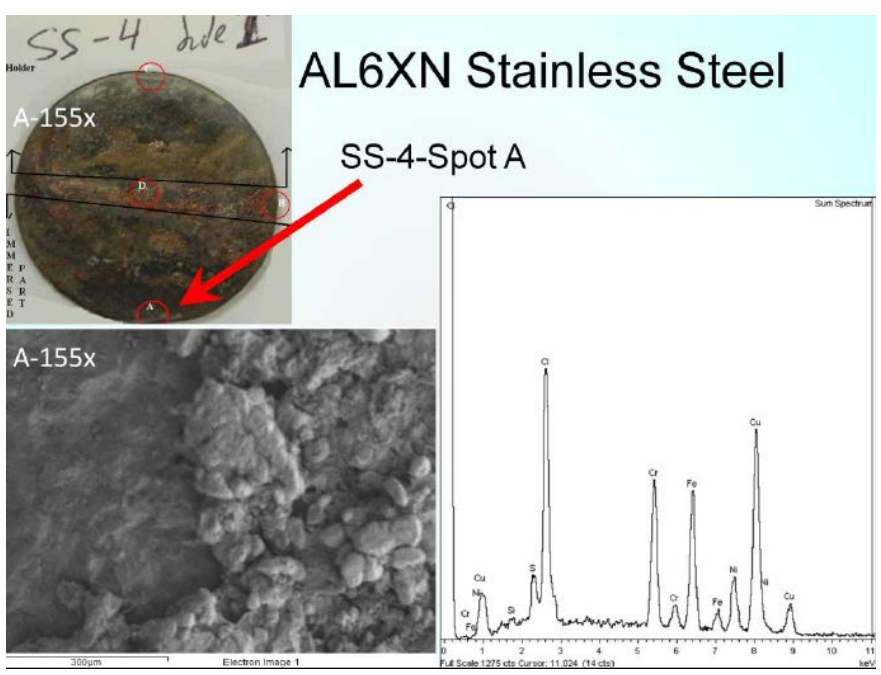

(b)

Figure 27: SEM and EDX results for (a) Inconel 625 and (b) AL6XN stainless steel 